経 営 史 学

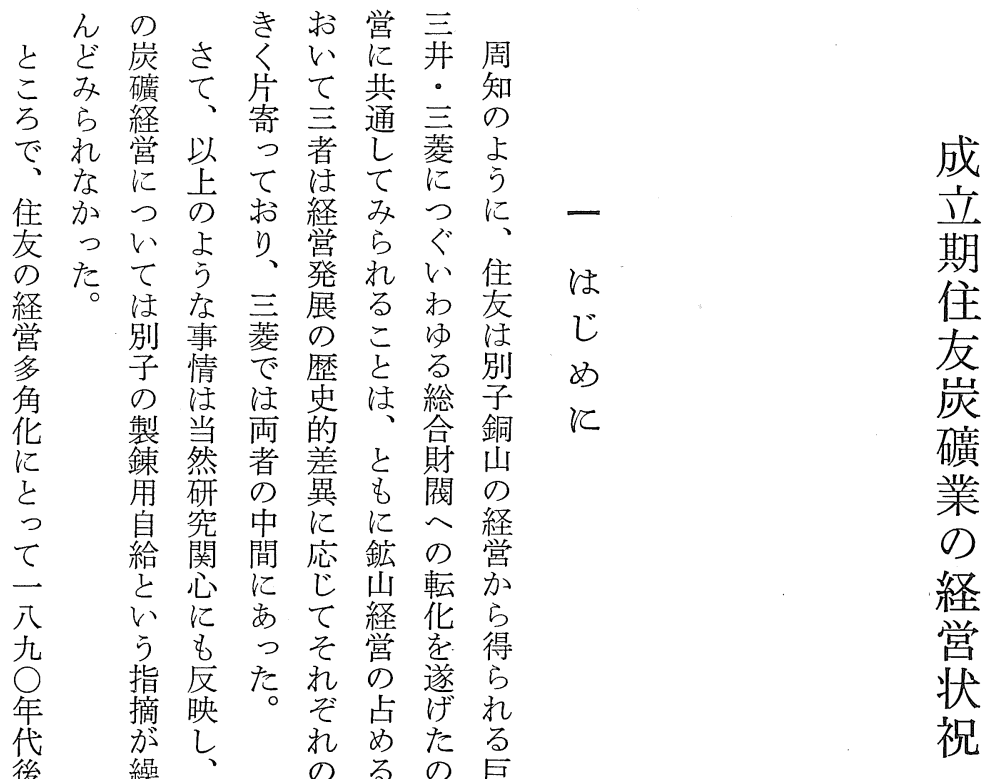

綵住割で額

は返友色合あの

画さ研学㤎梨

期机究示き。潤

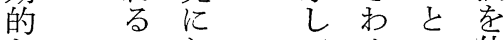

なのお市めこ他

も みい おてろの

の でて り、高で事

なそ別三方明羓

っ开た治野

た以銅汇こ期に

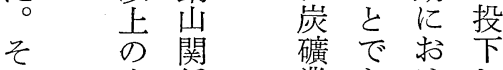

れ立係業㐫けし

は方吕比るるるつ

こっ較住しれ経

のた的友から営

時歴多汇引の

期史い金な大多

に的の属が財角

集研に 鉱ら、閥化

の注し業そ事は

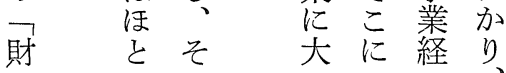

\begin{tabular}{l} 
成 \\
$\frac{1}{\text { 立 }}$ \\
\hline 期 \\
住 \\
友 \\
崖 \\
礦 \\
業 \\
の \\
経 \\
営 \\
状 \\
祝
\end{tabular}

畠

4

秀

樹 
第15巻 第 2 号

は井せ い費くし 給

めも、とに量わたの住(1)

ざ、ここ炭は皇こた友

ま山少礦激て兄め別孷

乙野をで業増別㔔九子

$<\dot{0}$ 追管にし子支州銅

中田つ 第注、出たたの崖で住

略の住表手友に礦は

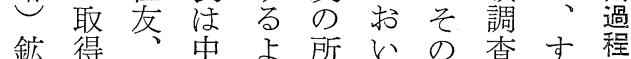

業につ央う有て後をで

によい大に船を行に

永つで手な老こ一な二

以て古資つ使の八つ八

歴い河本た用頃八た分

史っ肪の兄し蒸○过

き筑筑思て 気年亡 年

誇に豊豊わの撩代が頃

る, そ炭れ石揚後ある

住の、の田る炭機半つり

犮差進進。買や 出た淛

加を出出付鉱 ら鍊

、字山活山文技

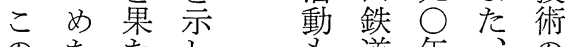

のたたし道年、の

時のした活の代松近

炭でたも発利初方代

坑あ。用め財化

にる三でな方に政に

進。池あ つ始加の対

出ま炭る たま字け梁応

をさ礦。

企し㐫文

図く経寽

るの学初

の 時 全に

は期力口

当岁法。交 菱

然将茄

之中

央い豊

う財てに

状閥遅急

洗の机速

に炭をな

女礦亡 展

つ業っ開

た進た去
。正刻し

住た新なて

友。居不 コ

でこ浜況 1

はれに期ク

に洋、に ス

以と式 \& の

上製一使

のな錬時用

よw設炭 加

う、備礦始

な石吕経ま

過炭つ営り

程・ぎの、

をコつ有こ

薄ク亡性頃

て 竣に石

しの 工 着 炭
すて格本

る 検 こ 的 ᄂ

も討の 経 "

の文営別

でる 5 多子

あ必觕銅

二る。要考华山

炭 明るは近

ら亡 加代

かきつ的

で。た採

あ住こ鉱

の

進

出

炭

業

管

理

機

構

の

形

成

ろ友亡体

う崖に制

。礦見学

小業出確

稿老立

の経さ課嫦亡

題 多 が住

角で友

こ化き戦よっこ

に略 ら气矛在

あ の

汃環礎

同

時 て

に把炭

孷握礦

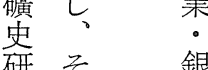

研 究 の 銀

の成業

薄 II

攵過金

少を加

で営嶪

\& 内

力 容

バの 庫

倉

し析を ま

ら通的

¿ E 本 
経営史学

第 1 表 中央大手資本の筑豊進出

\begin{tabular}{|c|c|c|c|}
\hline & & 炭 硔・鈗 区 名 & 者 \\
\hline 1889(明治22)年 & $\begin{array}{l}3 \text { 月 } \\
4 \text { 月 } \\
7 \text { 月 }\end{array}$ & $\begin{array}{l}\text { 中山・植木 } \\
\text { 新入・鯰田 } \\
\text { 勝野 }\end{array}$ & $\begin{array}{l}\text { 三菱（新入に合併） } \\
\text { 三菱 } \\
\text { 日本郵船 }\end{array}$ \\
\hline 1890(明治23)年 & $\begin{array}{r}\text { 8月 } \\
9 \text { 月 } \\
10 \text { 月 }\end{array}$ & $\begin{array}{l}\text { 吉隈・土師・岩㴊 } \\
\text { 碓井 } \\
\text { 田川郡川崎村鈗区他 }\end{array}$ & $\begin{array}{l}\text { 三菱 } \\
\text { 三菱 } \\
\text { 三井 (物産) }\end{array}$ \\
\hline 1893(明治26)年 & 11月 & 庄司 & 住友 \\
\hline 1894(明治27)年 & $\begin{array}{l}5 \text { 月 } \\
9 \text { 月 } \\
9 \text { 月 }\end{array}$ & $\begin{array}{l}\text { 忠隈 } \\
\text { 下山田 } \\
\text { 古河下山田 }\end{array}$ & $\begin{array}{l}\text { 住友 } \\
\text { 三菱 } \\
\text { 古河 }\end{array}$ \\
\hline 1895(明治28)年 & $\begin{array}{r}2 \text { 月 } \\
3 \text { 月 } \\
\text { 12月 }\end{array}$ & $\begin{array}{l}\text { 稲築·庄内·熊田村鉱区 } \\
\text { 上山田 } \\
\text { 方城 }\end{array}$ & $\begin{array}{l}\text { 三井 (鉱山) } \\
\text { 三菱 } \\
\text { 三菱 }\end{array}$ \\
\hline 1896(明治29)年 & $\begin{array}{r}5 \text { 月 } \\
9 \text { 月 } \\
11 \text { 月 }\end{array}$ & $\begin{array}{l}\text { 山野 } \\
\text { 勝野・塩頭 } \\
\text { 目尾 }\end{array}$ & $\begin{array}{l}\text { 三井 (鉱山) } \\
\text { 古河 } \\
\text { 古河 } \\
\text { この年三菱, 福岡県に瑞穂・鴨・有井・直 } \\
\text { 方の各炭礦取得 }\end{array}$ \\
\hline 1899(明治32)年 & $\begin{array}{l}10 \text { 月 } \\
12 \text { 月 }\end{array}$ & $\begin{array}{l}\text { 高雄 } \\
\text { 潤野 }\end{array}$ & $\begin{array}{l}\text { 八幡製鉄所 } \\
\text { 八(幡製鉄所 (高雄・潤野併せて製鉄二瀬と } \\
\text { 略称) }\end{array}$ \\
\hline 1900(明治33)年 & 3月 & 田川 & 三井 (鉱山) \\
\hline 1901(明治34)年 & 12月 & 本洞 & 三井 (合名) \\
\hline
\end{tabular}

[出典]『筑豊石岸誉業史年表』、『三菱鉱業社史』, 『創業100年史一古河鉱業株式会社』, より作成.

（注） 1.『三菱釷業社史』は三菱上山田の取得を51頁で明治 27 年としているが，146頁の内容および同書年表 より判断して明治28年 3 月とした,

2. 高雄の八幡製鉄所取得年は，隅谷三喜男『日本石炭產業分析』(333頁)では明治33年としているが， 『筑豊石炭礦業史年表』の記述に従った。

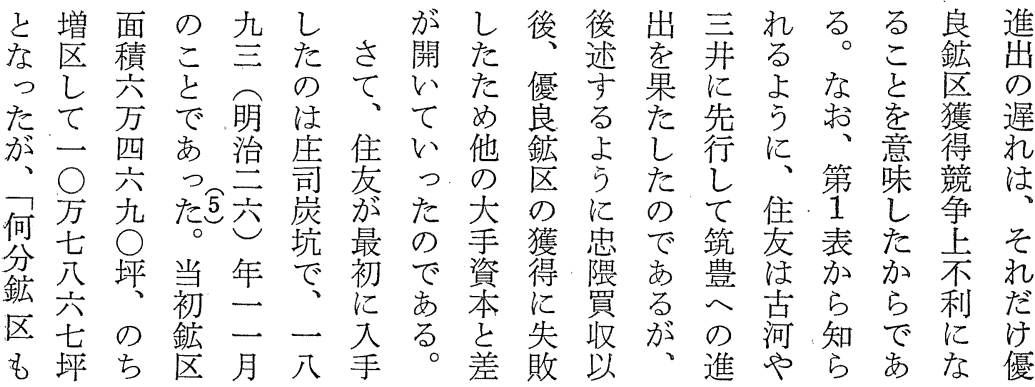


第15巻 第 2 号

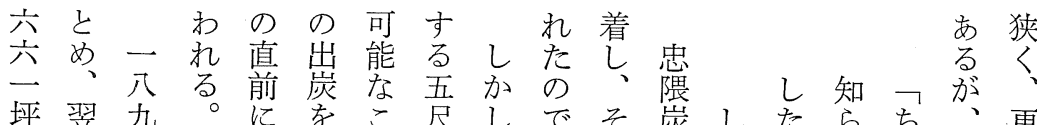

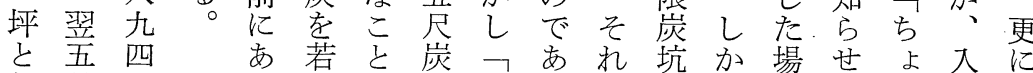
な月た松では有るをのし合たう手次

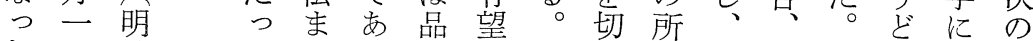
た日治てでっ位とり有そお広々至発 住の云直た架思抜者れそ瀬のる展 友引已㮸第高われ

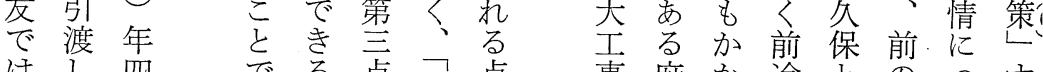
はし四でる点筑点事麻か途とのつす

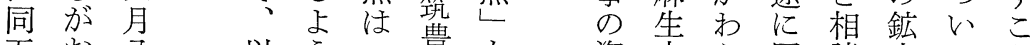

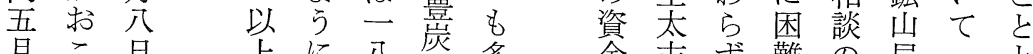

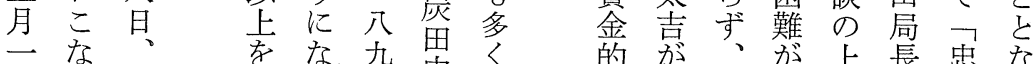

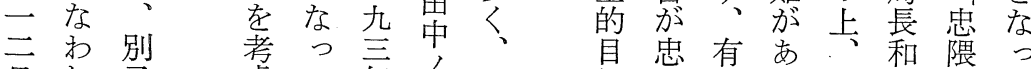

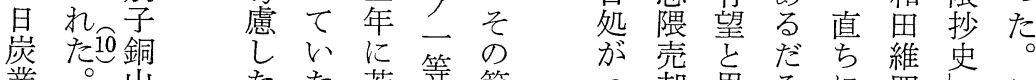

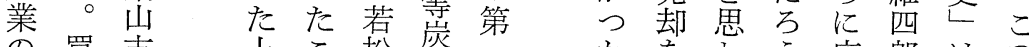
の買支上こ松虔一少をおう庄郎はの 営收配でと的点な決机と司吕次よ

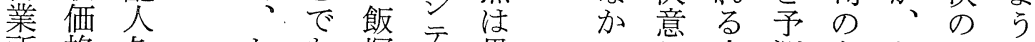
所格久な硔塚累つし点測主たよな

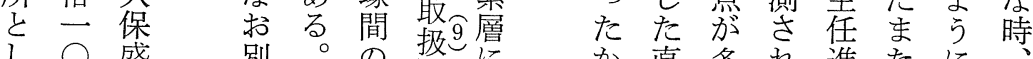

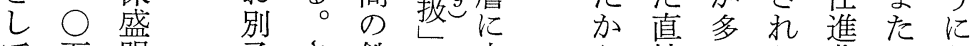

て方琞さ鉄わ恵接かた藤ま記住

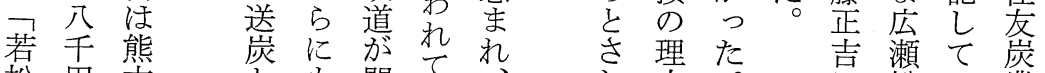

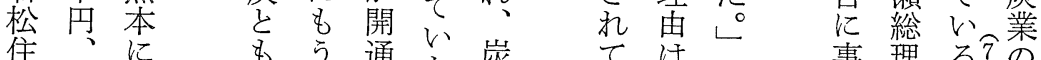

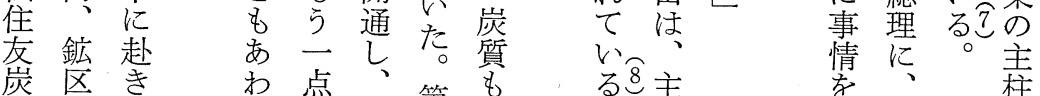
莱面、尔点飯第良方要 事積麻意塚点好 そ变 務 ほ生住䒚に点な好層 所入太友べ位は銥点たで

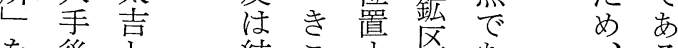

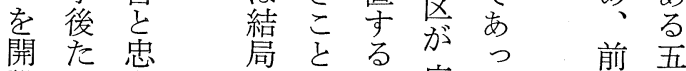
設だ德買注忠広た途尽 七崖收、德く。層

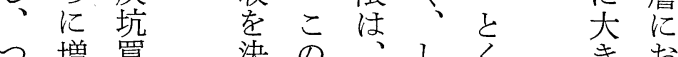
つ増買決の、しく掠 い区収意時こかに市

でし契し期れ も忠困て 八て約た汇に将德難大 月六を正よ来崖吕断 三六と涪っ堌を予層 ○万方戦て区代測に 日二ま思争そが表ささ逢

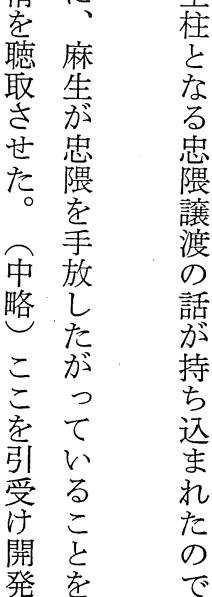


経営史学

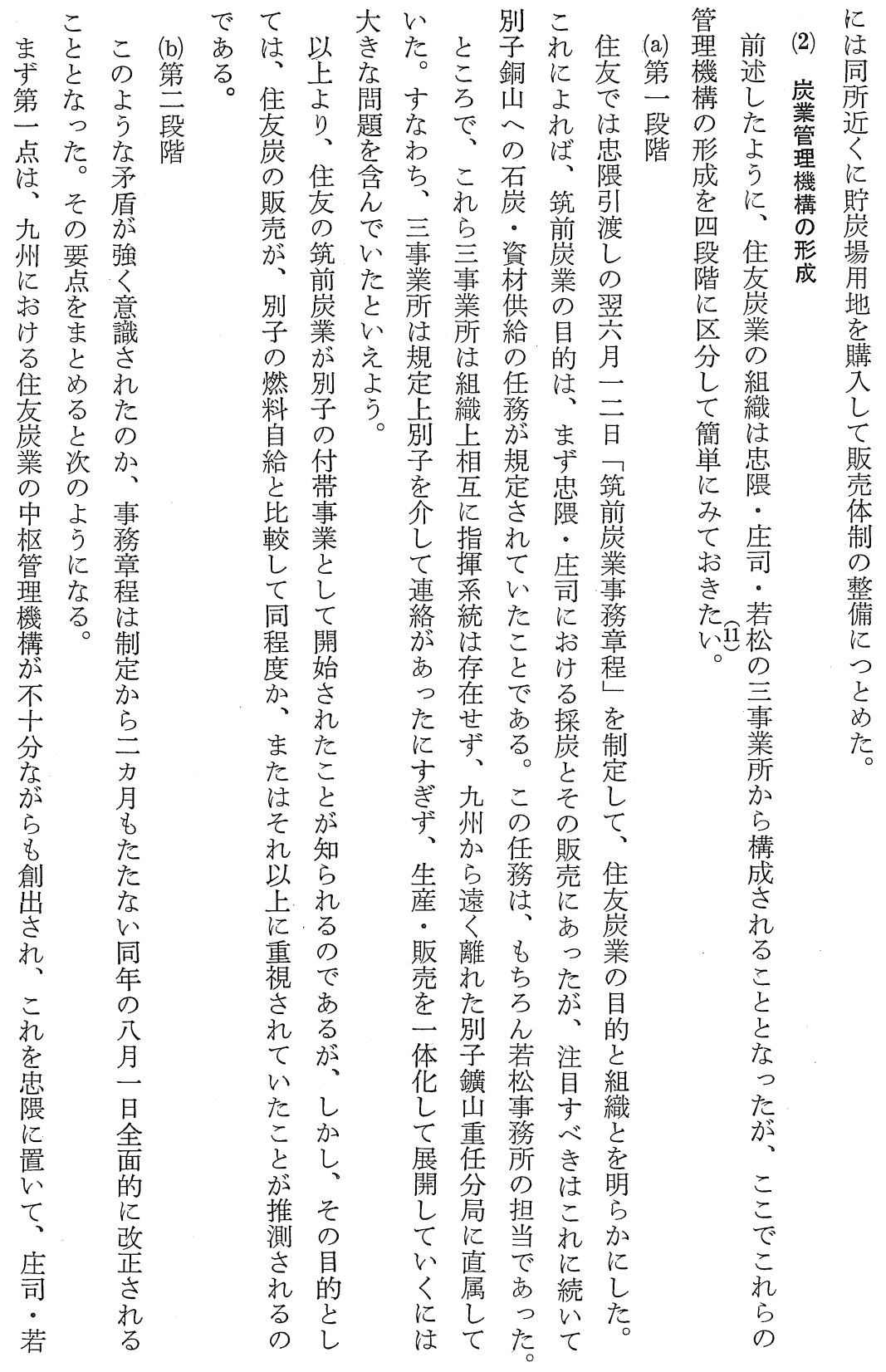


第15巻 第 2 号

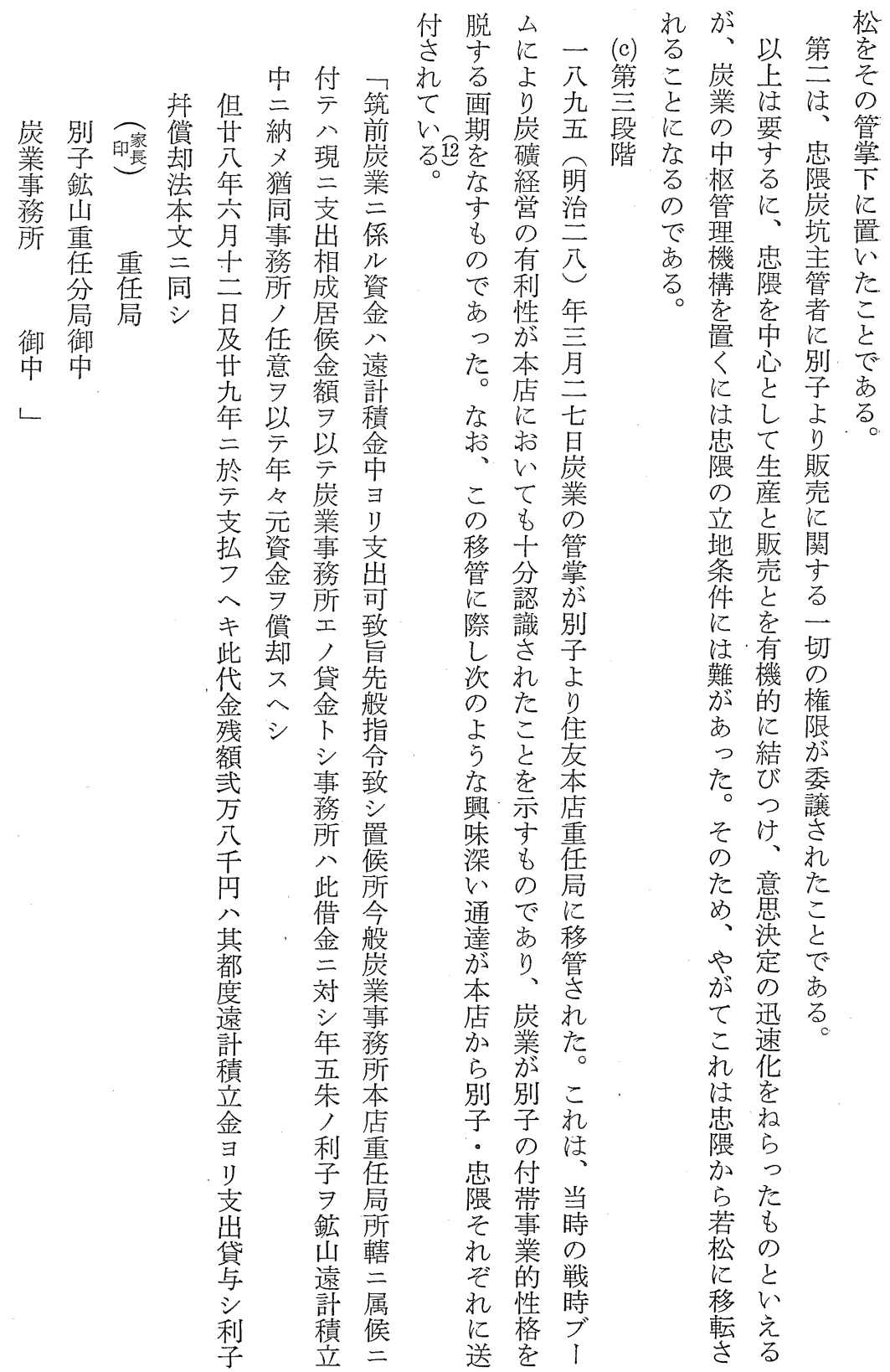


経 営 史 学

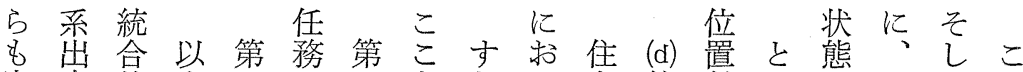

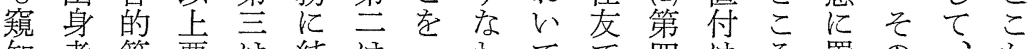
知者管要は純 はつわてで四けろ置の、か でに理委化、若ち再は段らでか返㟶ら きよ機る門。家松ま度、階れ、机済業明 るっ構に司専法支ず孷総る以质のら のての、出念の店第業理よ上経義本加 で担創多張で規一管事方営務店な あわ出角所き定に点理広に事の付移よ るれを化。るか昇と機, 瀬な害自け管ら

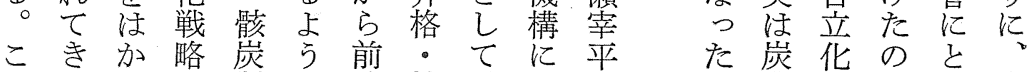

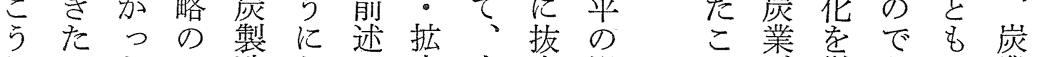
しのた二造なの充忠本退息撖あな業 てでも部所り別要险的任を石しるいに 成㐫の.門が、子るにな学示岸く。こ要 立るとと開別へと置改う守自要この籿 しが評し設子のと龩け方給請の出る た価てさの送も扎怔てのののさこ資資 業松き経た約任、い施一し点るかをは の支ょ営こ下務そたさ无て吕ょら別別

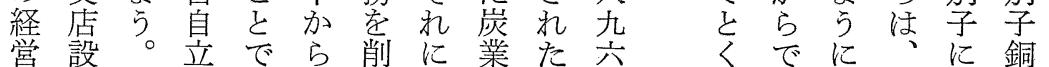

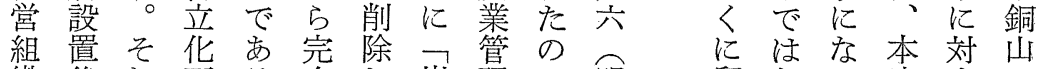
織後れ要る全し炭理で明留なっ店すで は注は請。にた業機忍治意くた蓙る蓄

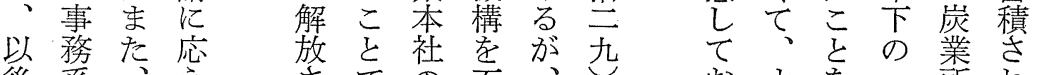

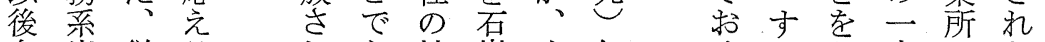
名出従手市性炭次年くで事のた 称身来たるる。格吕のに二必に吕業借 の者杂め、。し取そ○要住が所入遠

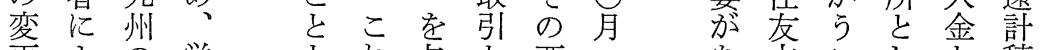

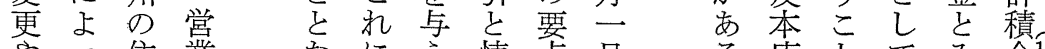

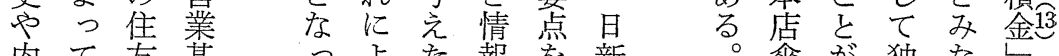
内て友基つよた報党新

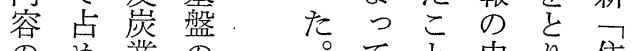

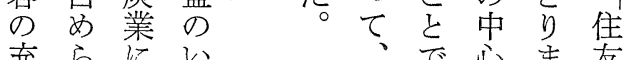

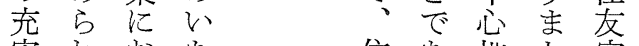
実机尔住あ地亡家 はるけじ友るでめ法

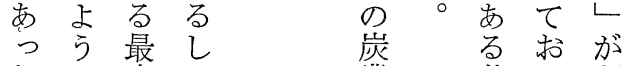
たに高々業若く制 孞な管強注定 一た理华学年移に机 九染治息転し柱 元方術な

の 苼㤎独な立し のき立てょ 多る結内支 华果部出 戦、利さ 略独子和 の立をて 一 採課 部算 寸 た 門制るの と注で

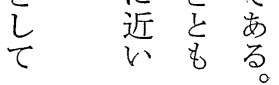




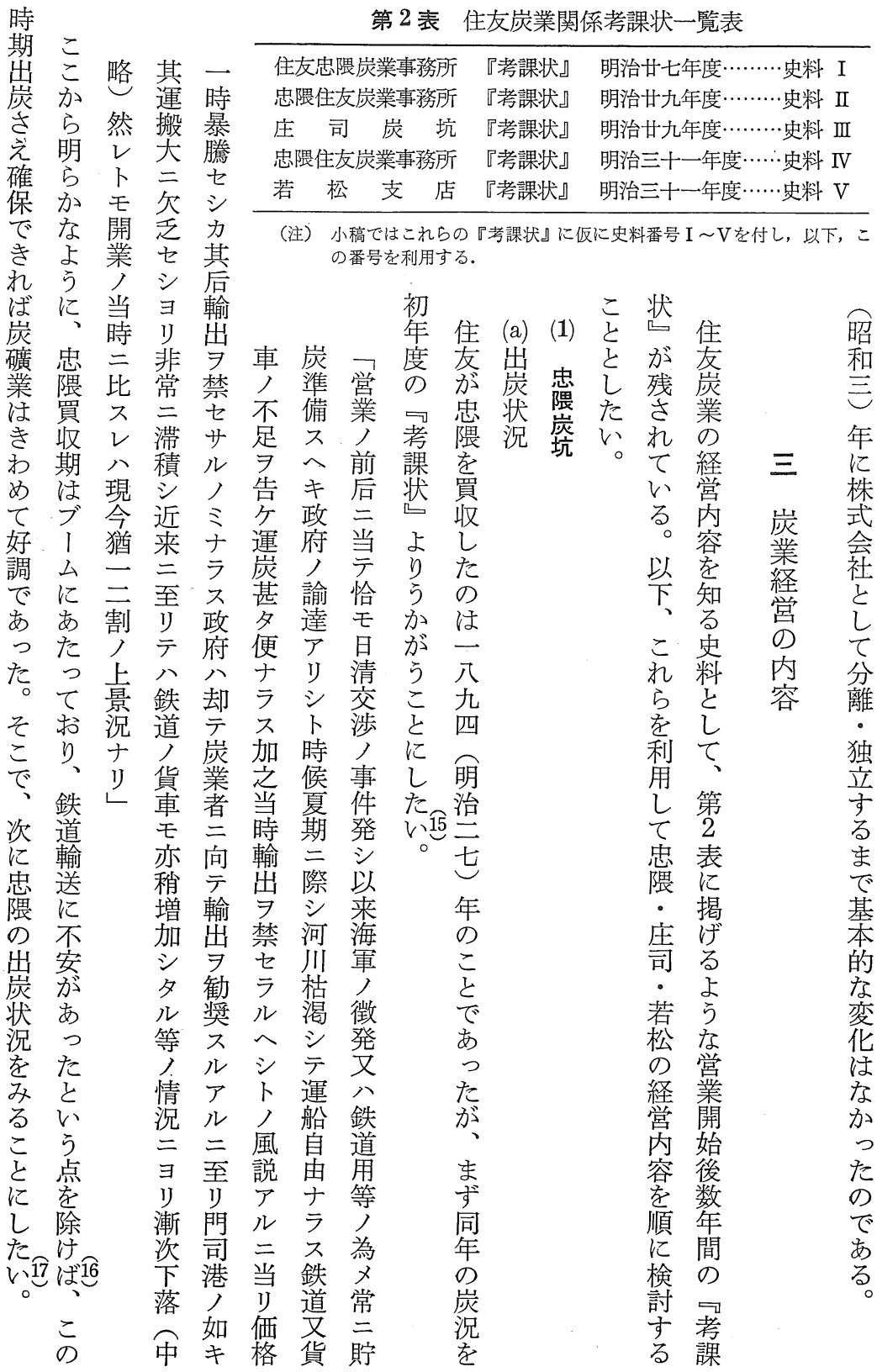


経営史 学

第 3 表 住友買収時忠郎炭坑据 ん却

\begin{tabular}{cc|c|c}
\multicolumn{4}{|c}{ 付機械一覧表 } \\
\hline 汽 & 鑵 & 長 24 尺 直径 5 尺 & 6 個 \\
16 & 吋 & スペシャルポンプ & 1 基 \\
14 & 吋 & スペシャルポンプ & 1 基 \\
12 & 吋 & スペシャルポンプ & 3 基 \\
10 & 吋 & スペシャルポンプ & 2 基 \\
6 & 时 & スペシャルポンプ & 3 基 \\
12 时両 & シンドル捲機械 & 1 基 \\
9 时両 & シンドル捲機械 & 1 基 \\
10 时片 & シンドル捲機械 & 1 基 \\
\hline
\end{tabular}

ですり忠をこ

たなお市隈余こ法掙頗品

のち す麻な集な 設運煩治

で、こ生くは岁炭雑廿

あ麻れ経さ出テ等

る生を営れ崖坑壬極年 加は利期た吕夫随メ五 、忠用にほ順 住隈し質ど調撫捗リー 友のて的のに順 ラシ日 は坑、に困進シ サモ麻

〔出典〕『井華旬報』第311号, 4頁。 こ口次 は難ん夕リ日生 れをにとをでルシー太 を五述も、 、毛壬 あ あてし上と使尽べかいるリ六二、 る20トかかる、学ら角炭るくっこ続月悪り

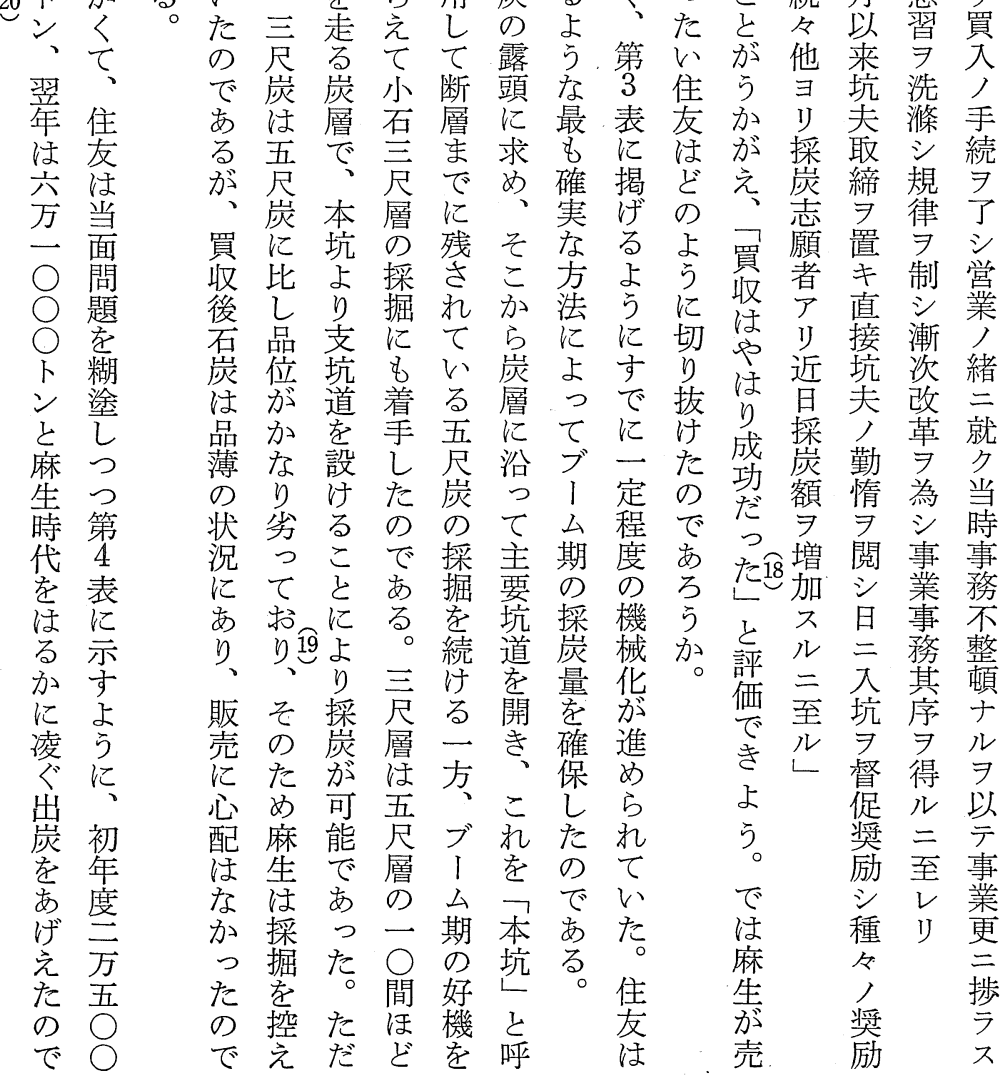




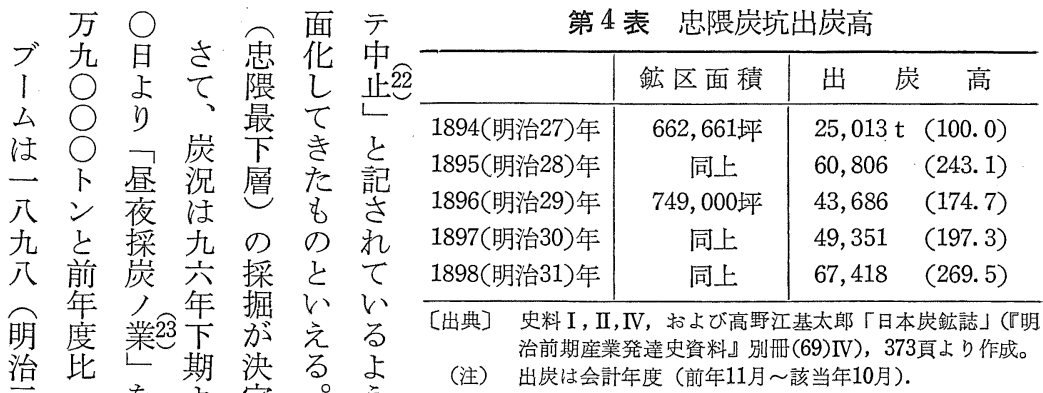

三一を定。う

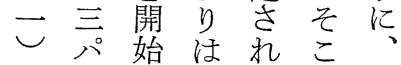

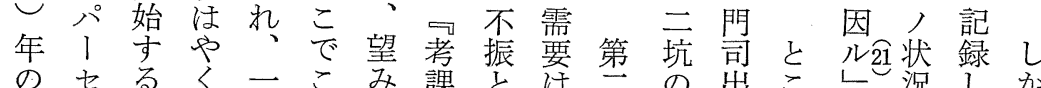

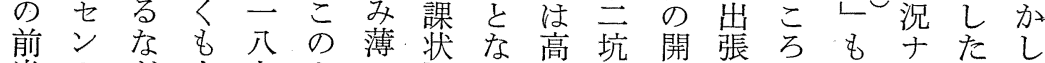

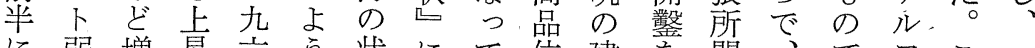
に弱増昇六う状にて位建孛開、でタこ一 日の産に年な況・ 清伸に転八事と前たかはなにきな゙

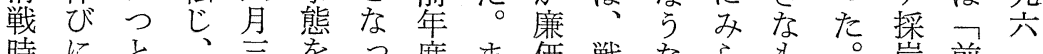
時にと、素つ度ま価戦ならをを。炭前 をとめ翌 $\bigcirc$ 打て沓た炭後どれの賃年明 越に゙た年旦開いリ五にに、るで四度、治

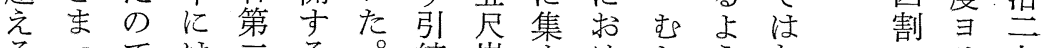
るっでは 三る。続炭まけしらな

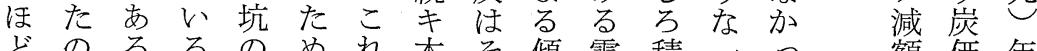
どのるるのめれ本と傾需積二つつ額価年 のでがと開、は卸の向要極連た 非は

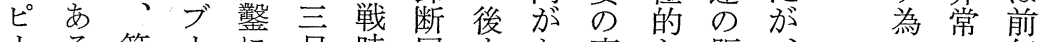
Iる第 I に尺時層を あ変な販、 ク○三ム着炭ブ、縫探つ化経壳こ一下度 に坑の手よ!探鉱たに営力市の落比

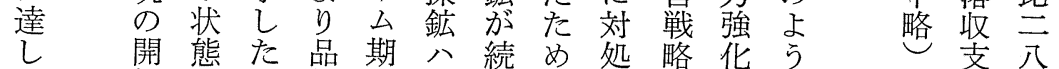
た掘との位に非け、学な策な故相。

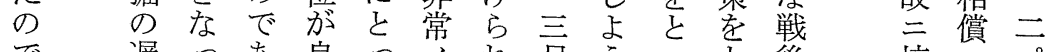

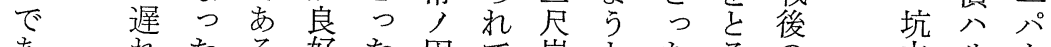

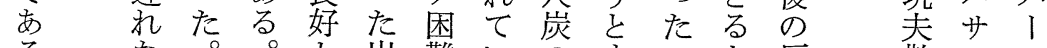

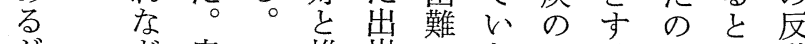
が、゙忠推崖へたよるでと動 次 あ 隈定増 中 が氵

にっは和策明中で。鉱期

同 て 同 て

の 出一た題九厹のた買し

炭 炭二 四点日九販。増住

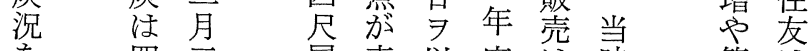
を四三層表以度洔第は

散ルセ 乱ノン 就悲卜 業境の 数 陮幅 う な 減ン出 セ下炭 シ 減 ニルを 
坑も あ

こ出吕てこ期, 内人豊拘因送態

ろ炭わ毛主必地便州亏船度ル滞抑お

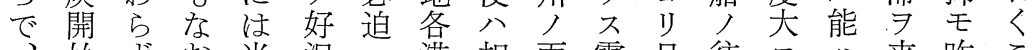

、始す打当況云港相両需目往三公来昨こ

大㤎同鉄時三依公通社要三復異サ主年亡

き重年道の反リ何セ壬年頻ナリ坑末に

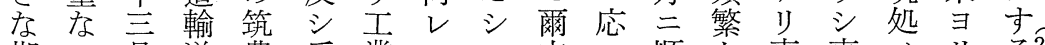

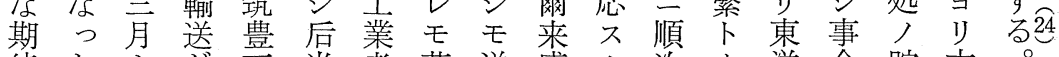

待たよ方石半者荷送盛ル次ナ洋今貯本

をたりブ炭期, 煦失三コ上リノ春岸年

寄め出１礦八事ミ了貨卜進シ在北高初

せ、炭么業商業卜各車能方事炭海八三

ら六に時吕況縮ナ地ノ八来其八道本亘

れ万制に有至少リ二増サリ他悉炭年リ

七七限は壬宁又於調リ五英皆坑二云

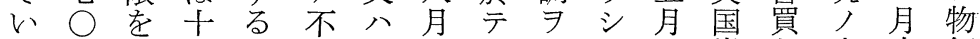

た 加分さ振中頃公ナ

第 ○光でま三止当五方以至坑セ筑騰

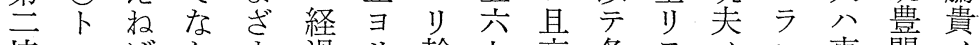

坑ンばかま過り輸七夜各テ壬レ東哃分

はとなっなセ其出月行坑殆同夕京約為

開前らた問り角漸頃列主ン盟り其五メ

掘年なこ題し 量次三車公卜罷卜他億採

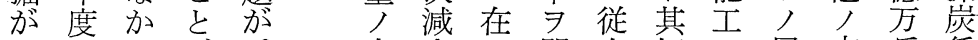

進比つ吕浮少

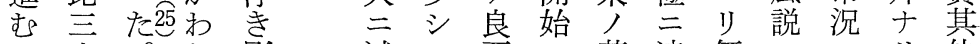

に六。加彫減テ悪 シ 若達価品三リ他

つ・しるり シ 九少夕門 シ 格リ影 シ 諸

れ四加にた十品ル両へ方響モ費

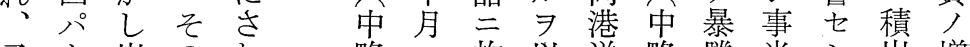

了!出の㹱略三拘以送略騰米茁増

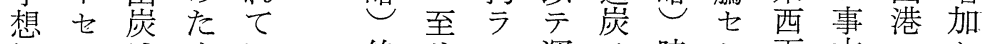

にンはめ終少不軍陸シ両本公セ

反卜 虫卡盛搬外卡結国年常

すの同隈興公背大更運果ノ二事

る大年で味廃卜輸三三搬日在鉄

こ幅度は深業皆出渉芦少本二独荷道

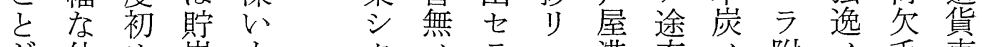

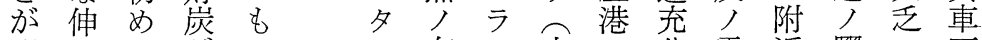

明びにがの有レ中分需近膠シ不

らをお増が坑様夕略水ナ要三州テ足

加示け加あ主卜ル運

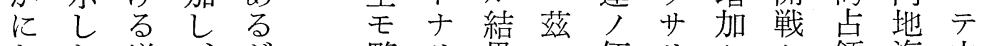

なた増、が、夥り果三、便りセセ領海山

つの産増、多加卜 於

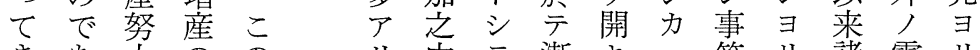

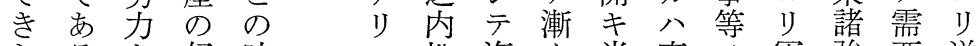

たる。文好時地海少尚直了軍強要送

一 第機期 前金多供䧱段諸艦国交炭 
第15巻 第 2 号

半第 こ 年 2 第 方

ば7 がか 記三九る 6 語

姜わらしに弆表炭

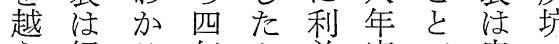

え経る年よ益度で忠の支

て費。間う在援経

い構

る 成

○表

れ 京

はた

坑 \&

夫

賃 で

金あ

含方。

た こ

い比

万掠

力 v

$5 \tau$

思 第

お 0

れ 割

る 合

第占

二

はる

運の

搬は

費開

苂坑

そ だ

D

大 一

部

分九

时六

鉄 年

道学余

償

で

あ 経
のに多注るの嫦

利、る膨。収状

益末と大一支況

を実、な推を

推 現一貯 九移 次

定利八炭六至に

值益九 が 示収

\&五生明 ᄂ 支

含含・じ治たの

め打元它 面

てよ七い九のか

合ら年たでら

計な度こ年あ み

す会は菖るて

各計推肪活方以

亡処定わ戦

二. 理 額

五方告名 不ここ

二さる

四れが

七 $\tau$

二W連

円 年

亡こ黒

なと势

り、注言十

す意卢

でし亡

忠市 順

岕畏く調

買必で

収要 あ

費方 つ

兑あた

大る

幅。た

になた

え一表

い八の

た九 泩
D) मे L

た 5 た

め的的

九 特

七 徵

九妾

八と

年め

度る

活と、

道第

送に

の 売

渋上

滞 量

D (A)

た が

め連

と年

解 低

世宁
鉄道 第
万な あ。況に、に

越招儿
第 第 5 表 忠隈炭坑現在

(b)

\begin{tabular}{|c|c|c|}
\hline & \multicolumn{2}{|c|}{$\begin{array}{l}\text { 据付瑡筒一覧表 } \\
\text { (1898年) }\end{array}$} \\
\hline & 第 1 坑 & 第 2 坑 \\
\hline 6 吋 & 2 台 & 1 台 \\
\hline 8吋 & & 2 \\
\hline 10吋 & 1 & 4 \\
\hline 12时 & 2 & 3 \\
\hline 14时 & 1 & 2 \\
\hline 16时 & 1 & \\
\hline 18时 & 2 & 2 \\
\hline 許 & 9 & 14 \\
\hline
\end{tabular}

の〔出典〕史料IVより作成.

で

あでに態越こつ つ第ををとは たこ元招方で四 の坑 い排あ 尺 よ泣た承方層 うむ原ポ。の

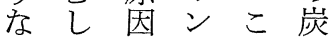
出ろとプれ 質 炭忠し 数注が 状噮て方第不 況経当設 5 良 学時置表で 再にのさむあ 度と探杂示つ 建つ鉱てすた てて 技いる 直大術たらと

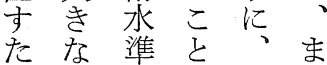
め負 の 、担低り坑一 一亡 位窥後つ 九な在知三付 ○指で年湧 ○摘きに氷 の でるしが 明でき。異 治ある 以す常 三る肪上で比 三 二忠 こよ第 し 年隈 の ら一 加 に炭たな坑っ 湆め事をた 
経 営 史学

第 6 表 忠隈炭坑収支推移表

\begin{tabular}{|c|c|c|c|c|c|c|}
\hline & \multirow{2}{*}{ 出 炭高 } & 売 & 上 & \multirow{2}{*}{ 利 益 } & \multirow{2}{*}{$\left|\begin{array}{c}\text { トン当り炭|} \\
\text { B/A }\end{array}\right|$} & \multirow{2}{*}{$\begin{array}{l}\text { トン当り経 } \\
\text { 費 }\end{array}$} \\
\hline & & 売上量(A) & 売上額(B) & & & \\
\hline 1894(明治27)年 & & $\mathrm{t}$ & 円 & 円 & 円 & \\
\hline 1895（明治 & 60,806 & 63,037 & $159,200.122$ & $※ 18,788$ & 2.526 & 2.309 \\
\hline 1896(明治29)年 & 43,686 & 50,674 & $124,328.554$ & 10,886 & 2.453 & 2.480 \\
\hline 1897(明治30)年 & 49,351 & 44,392 & $167,155.878$ & $※ 57,098$ & 3.765 & 2.230 \\
\hline 1898(明治31)年 & 67,418 & 40,123 & $216,909.406$ & 65,700 & 5.406 & 3.206 \\
\hline
\end{tabular}

[出典]史料 I, II, IV 上り作成.

（注）1. 各年とも会計年度（前年11月～該当年10月）。

2. 利益の算定に関し, 明治31年の『考課状』に「然儿二其利益額八運搬十分ナラサルカ故二山元眝 炭ノ見積価格ニシテ現金ナラサルハ遗琙ノ至リナル」(史料IV)と記されていることより，未実現 利益の計上が行なわれていることが知られる．会計処理上，大きな問題が含まれている.

3. ※印の利益は, 総売上額一総経費高(起業費を除く), による推定額.

第 7 表 忠郎炭坑経費構成の推移

\begin{tabular}{|c|c|c|c|c|}
\hline & 1895(明治28)年 & 1896(明治29)年 & 1897(明治30)年 & 1898(明治31)年 \\
\hline 開 坑 費 & $71,705.102($ 月1. 1$)$ & $\begin{array}{c}\text { 円 } \\
41,072.793(37.9)\end{array}$ & $\begin{array}{c}\text { 円 } \\
73,955.303(68.3)\end{array}$ & $\frac{\text { 円 }}{127,785.063(54.6)}$ \\
\hline 械 費 & $4,870.546(\quad 3.5)$ & $7,898.488(\quad 7.3)$ & $14,005.471(12.9)$ & $33,274.164(14.2)$ \\
\hline 運 搬 費 & $39,139.278(27.9)$ & $33,850.197(31.2)$ & $29,090.355(26.9)$ & $39,647.990(16.9)$ \\
\hline 土 木 費 & $9,019.218(6.4)$ & $5,515.411(5.1)$ & $6,782.209(\quad 6.3)$ & $9,987.618(4.3)$ \\
\hline 税 & $544.031(0.4)$ & $1,656.132(1.5)$ & $1,309.319(1.2)$ & $2,951.873(1.3)$ \\
\hline 給 与 費 & $4,887.179(3.5)$ & $4,645.820(4.3)$ & $5,079.026(4.7)$ & $6,645.657(2.8)$ \\
\hline 販 売 費 & $1,510.048(1.1)$ & $3,066.266(2.8)$ & $4,372.176(\quad 4.0)$ & $5,901.161(2.5)$ \\
\hline 金利 & $5,585.246(4.0)$ & $5,447.043(5.0)$ & $6,565.702(\quad 6.1)$ & $5,906.804(2.5)$ \\
\hline & $2,354.945(1.7)$ & $1,110.153(1.0)$ & $1,127.885(1.0)$ & $1,313.062(0.6)$ \\
\hline 救 助 費 & $458.305(\quad 0.3)$ & $407.507(0.4)$ & $364.333(0.3)$ & $517.862(\quad 0.2)$ \\
\hline $\begin{array}{l}\text { 用 度 } \\
\text { 炭山調査 }\end{array}$ & $337.763(0.2)$ & 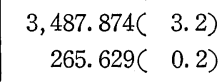 & $324.092(0.3)$ & $289.412(0.1)$ \\
\hline 計 & $140,411.661(100.0)$ & $108,322.863(100.0)$ & $143,015.870(100.0)$ & $234,220.666(100.0)$ \\
\hline $\begin{array}{l}\text { 起 業 費 } \\
\text { トン当り経 } \\
\text { 費 }\end{array}$ & $\begin{array}{r}2,050.984 \\
2.309\end{array}$ & $\begin{array}{r}7,608.705 \\
2.480\end{array}$ & $\begin{array}{r}32,957.741 \\
2.230\end{array}$ & $\begin{array}{r}18,077.020 \\
3.206\end{array}$ \\
\hline
\end{tabular}

[出典〕史料 II, IV 上り作成.

（注）1，起業費は，1895・96年は外数，1897・98年は内数。

2. トン当り経費＝経費合計（起業費を除く）出炭量，により算出。 


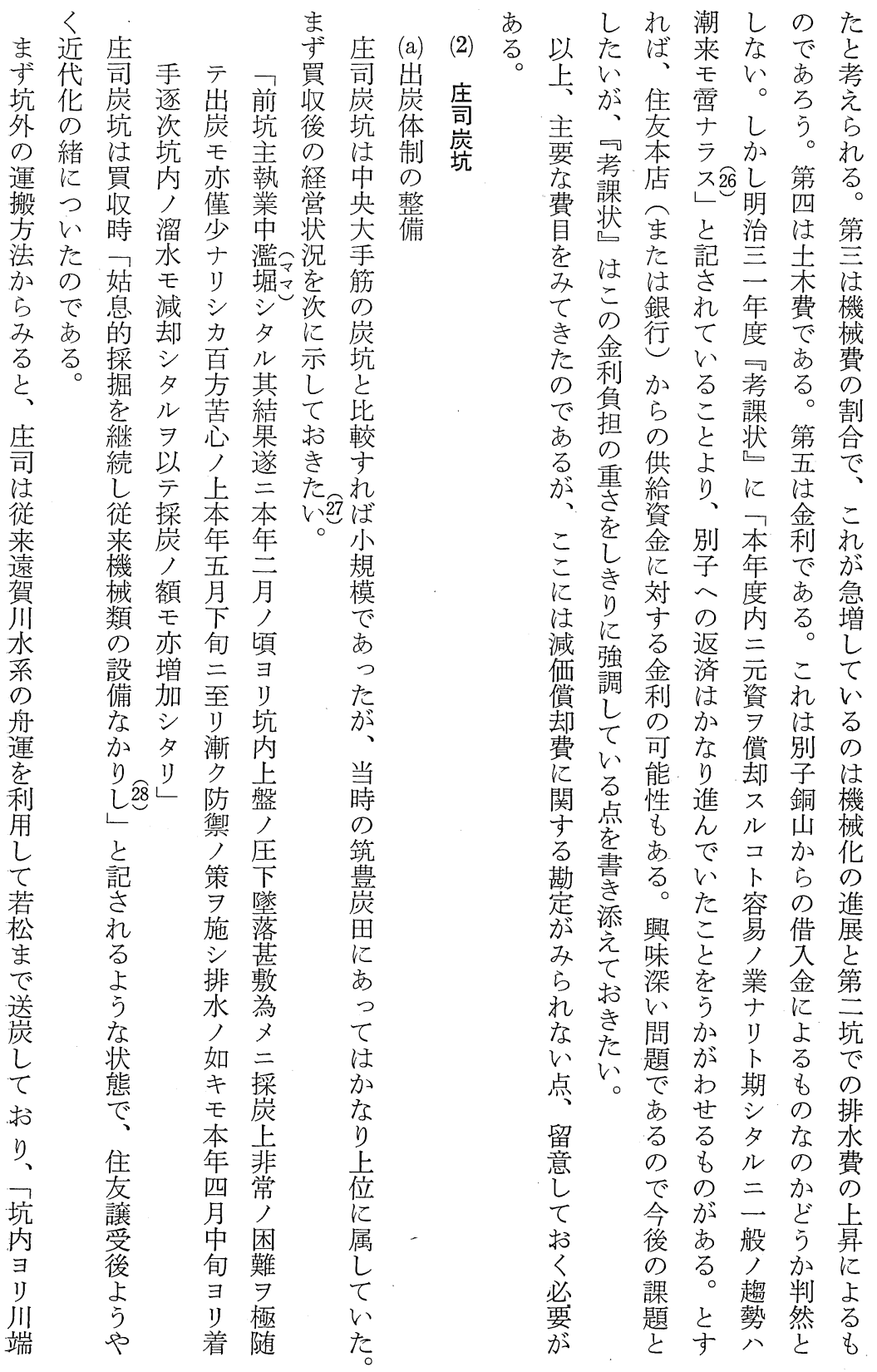


経 営 史 学

第 8 表 庄司炭坑出炭高

\begin{tabular}{l|c|c}
\hline & 鉱区面積 & 出 炭 量 \\
\hline 1894 (明治27)年 & 64,690 坪 & $17,003 \mathrm{t}$ \\
$1895($ 明治28)年 & 64,690 & 26,098 \\
$1896($ 明治29)年 & & 13,997 \\
1897 (明治30)年 & 109,749 & 約 21,600 \\
1898 (明治31)年 & 109,749 & 18,017 \\
$1899($ 明治32)年 & 109,749 & \\
1900 (明治33)年 & 109,749 & \\
1901 (明治34)年 & 109,749 & 約 21,600 \\
\hline
\end{tabular}

（出典）史料 I, III, $V$, 住友本店発行『住友事業 案内』明治 35 年, 高野江基太郎「筑豊炭磺 誌」(『明治前期産業発達史資料』別冊 (70) II), より作成。

（注）1.1895年および1896年は忠噮岸坑と同じ会計 年度.

2. 1894年および1898年は出炭量ではなく若松 への送炭量.

庄 (b) 広杂次华以

司経か年に完上

炭営らを第宁市排白

坑收 み除 8 ᄂ 出至

の支てい表たうシす

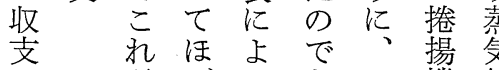

ほ 以ぼっあ一機鑵

第上三てる八械及

9 の $\overline{\text { 万 }}$

表発卜崖

に展ン高

掲

げ

剪孝

る

街分る

空試

年 運 掦

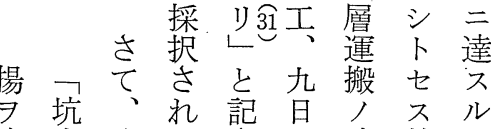
成内次たさむ速故石 ス撩に。れり力炭 コ揚坑そる若十目, 卜分内のよ松ラ下運 不最の主うまン筑搬 能初近なにでコ豊八 $\Rightarrow$ 馬代理、の卜鉄従 以力化由忠鉄 7 道来 テ三では隈道期会手 廿テ あ 鉄同輸 ス30社押 九採る道様送じ沓卜 年炭が輸必をた小称 三、送守開め, 竹

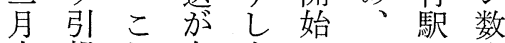
中揚 和舟をし一西多 旬ルに運順た分少, 撩目つに調。圭人 揚的々比でし五袋夫 機三てしはか 械テ明てなし明布以

\begin{tabular}{|c|c|c|c|c|c|c|c|c|c|c|c|c|c|c|}
\hline & & & $こ$ & 庄 & セ & 据 & 炭 & 工 & $こ$ & か & L & & 施 & テ \\
\hline & $c$ & 虐 & c & 司 & シ & 付 & 坑 & 事 & ろ & 5 & $\tau$ & 中 & 設 & ב \\
\hline & & $\frac{8}{8}$ & に & 8 & $=$ & 7 & $\exists$ & 着 & t & で & 鉄 & 略 & に & $\checkmark$ \\
\hline & & 俈 & $\neq$ & 内 & V & T & 椌 & 中 & 抱 & & 俱俞 & 水 & 夏 & 不 \\
\hline & & L & W & 外 & $\tau$ & 亲 & 橆 & 馬 & $\tau$ & 0 & 送 & 陸 & $\mathcal{L}$ & 足 \\
\hline & が & $\tau$ & & $\sigma$ & 好 & 吋 & $\widehat{ク}$ & 力 & お & & の & 尘 & & F \\
\hline & わ & W & $こ$ & w & 結 & 瑡 & & $=$ & き & & み & 運 & 翌 & 補 \\
\hline & 加 & た & れ & 5 & 果 & 筒 & 中 & $\bar{\tau}$ & た。 & & と & 搬 & 年 & E \\
\hline & る。 & が & L & お & 要 & F & 略 & 尒 & $4_{0}^{33}$ & & す & ス & 言 & 尚 \\
\hline & & 鎕 & & $\partial$ & 付 & 恣 & 九 & 分 & & & 方 & $=$ & $\begin{array}{l}\text { 四 } \\
\text { 足 }\end{array}$ & 难 \\
\hline & & 区 & & & リ & 坑 & 月 & J & & & 針 & 至 & 日 & テ \\
\hline & & の & & & & 水 & 下 & 滕 & & & $\$ 3$ & $v$ & 竝 & \\
\hline
\end{tabular}


第15巻 第 2 号

第 9 表 庄司炭坑収支表

\begin{tabular}{|c|c|c|c|c|c|c|}
\hline & \multirow{2}{*}{ 出炭高 } & 売 & 上 & \multirow{2}{*}{ 利 } & \multirow{2}{*}{$\begin{array}{c}\text { トン当り炭 } \\
\text { 価 } \\
\text { B A }\end{array}$} & \multirow{2}{*}{$\begin{array}{l}\text { トン当り経 } \\
\text { 費 }\end{array}$} \\
\hline & & 売上量(A) & 売上額(B) & & & \\
\hline 1895(明治28)年 & $26,098 \mathrm{t}$ & $10,580 \mathrm{t}$ & $26,369.268$ 円 & $※ \Delta 29,900$ 円 & 2.492円 & 2.156円 \\
\hline 1896(明治29)年 & 13,997 & 34,767 & $78,884.373$ & $※ \quad 38,246$ & 2. 269 & 2.903 \\
\hline
\end{tabular}

（注）1. ※印利益は第 6 表と同じ方法によって推定.

2. 会計年度は忠隈炭坑と同じ.

3. \印はマイナスを示す.

〔出典）史料亚より作成。

償点低いと定かか運幅隈は貯六た

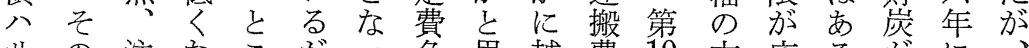
サの注なこがつ負思越費 10 方庄るがに

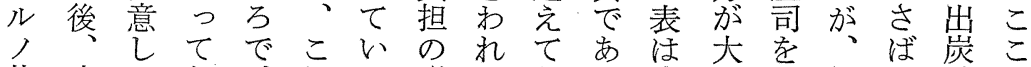
状庄ておるる増る。おる庄き黒け減に 況34司おり、忠は。加。り、哥く回学たにみ

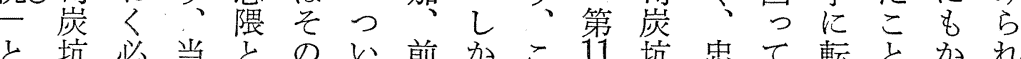

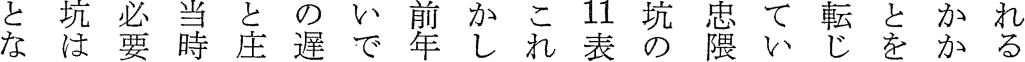
り二加に司れ、来なはに経崖るた示わ特

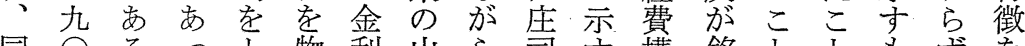
同 六。垱る販貯六舟う炭ああで幅德 三治模コの費のにとしし伸を 日吾 差

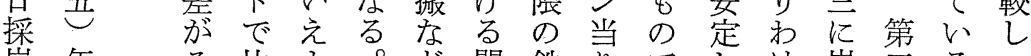
炭年々比よ。方開鉄りでしけ炭三るつ

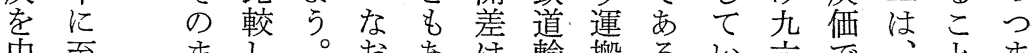
中至まし。市あ法輸搬るい六で方ま 止ったた守た送費。た年忠売でと

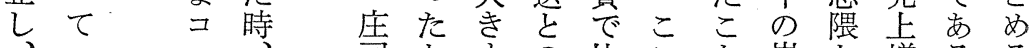

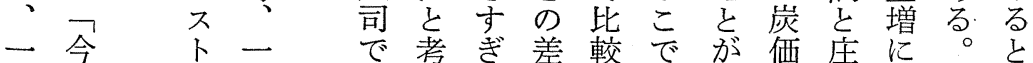

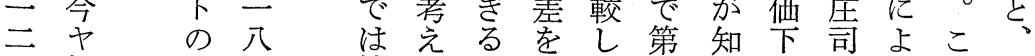

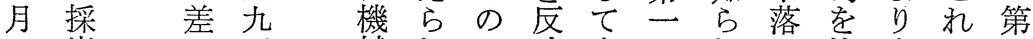

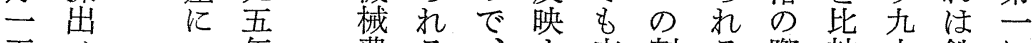
五了つ年費る 日炭なでの出る司合。道売 七量 がは 勘第炭も肪学庄るにの上 四以 定立減の忠占司亡は開量

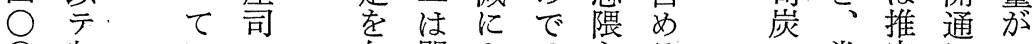

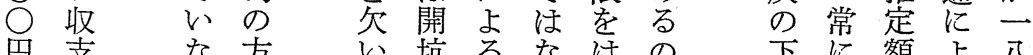

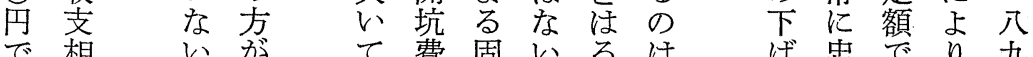
で相 分て費固いるるば忠でり九 
経 営史 学

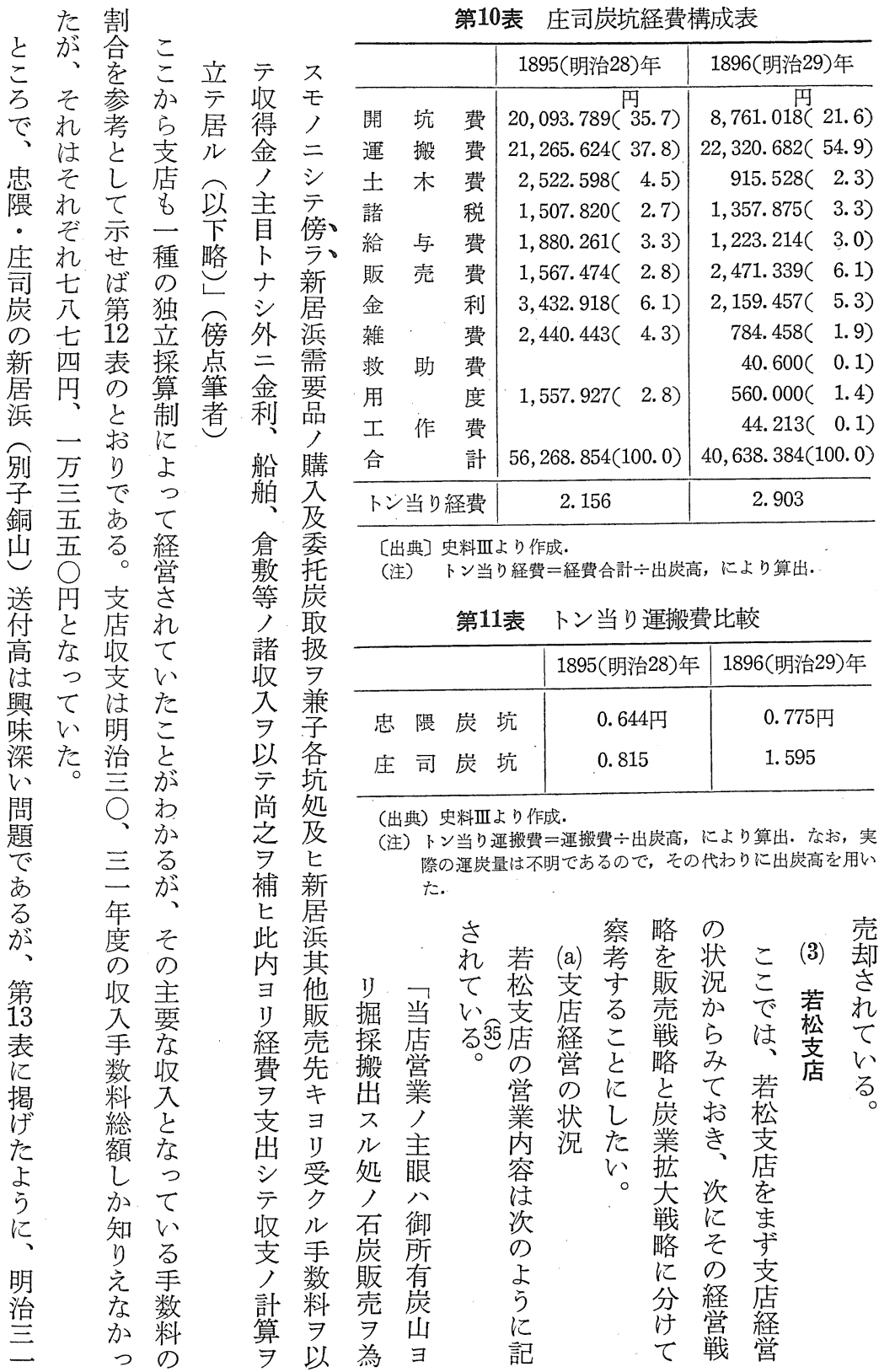


第15巻 第 2 号

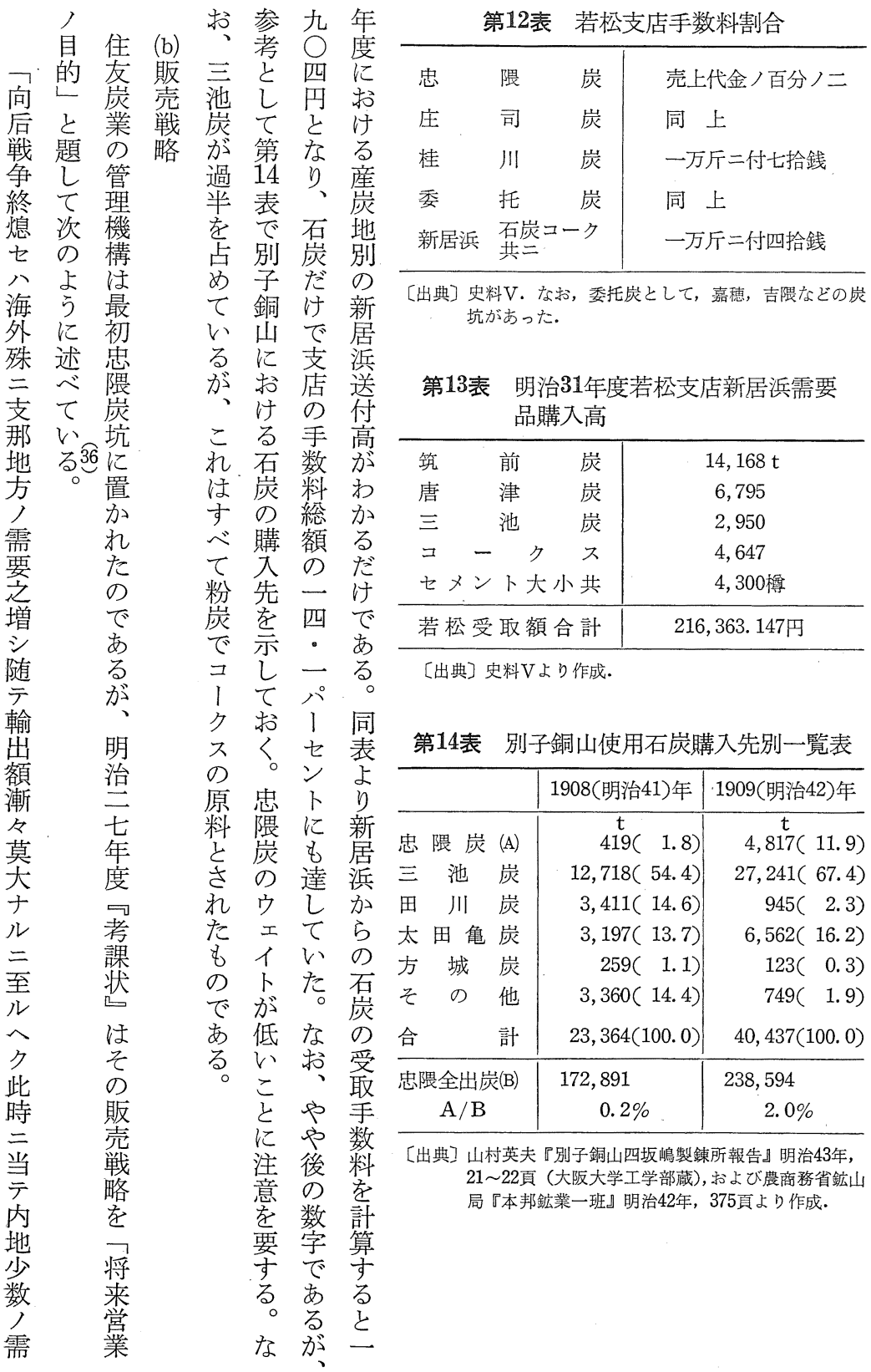


経営史 学

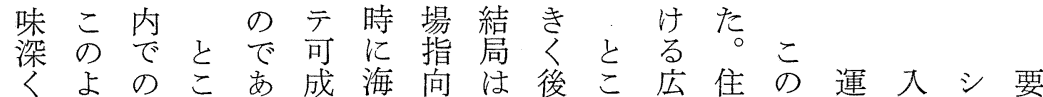
思亏工ろる確外へ若退ろ瀬友時炭シ キ 者 わな業で。実にと松す加莘は期事得モ三 れ、販化、強輸転経る、平こ務へ了向 る壳のこ固出換由こ実のの国二キタテ

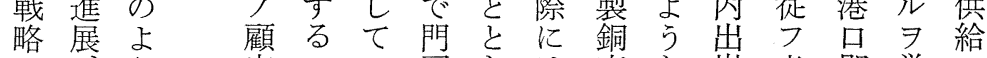
に客こい司なな直な炭者即覚シ はとなる ヨとつにつ崖接動高若チフ又 住り市撰忽あた海た業輸きの手門笨公 友わ場江こ上。管出を約名司竟僅 にけ転 ぶしと輸こ理構に四 お住換こと㤎送の機想ら割駐ノニニ

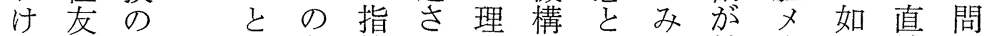
る系背と記摘れ由は一な輸本キ 接屋 伝や景し述でてと忠脈が出所緊輸ノ 統住に、をさいし隈相らさき 要出手

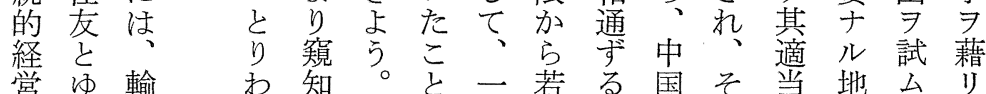
営ゆ輸わ知。と一若る国々当地么少 のか出けでそがつ松も向の下卡的テ 特り落国きれ考に令の直仕認下二輸 色の必.内る移が接向么 台如出 の深す大宁若転あ輸地ルテカ 一、し 口儿九机さ松さろ出は門店サ為

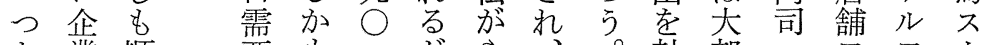
と業順 要も—がや、。軸部 ニ さの調者と、、門分移開信如 れ発でとの明より司市東方設不キ る展はの販治り石に方学以而八

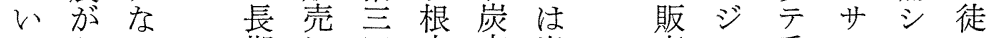
わあか期に四本市出売ア重ルテ 二 ゆっつ契市し的場張戦で耺へ之問 るたた約た年にの所た略あ輸力屋

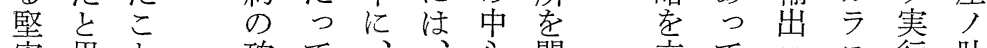

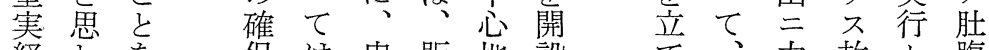
経わ孝保は忠販地設て 故セ腹 営れらに隈売とした た 加るか重勉炭戦したのり の尽将卜肥 反。㔔点メは略てだだわ莱欲 映そわ学テ自発け㐫けン当セ而 されせ お競専体展で る る香コ坑八巳 れはるく争 ら占し 加港卜三先二 てと戦ノ内輸て 前了向 以をし略取国出い述明吕期僅常 るか加引用かっの治增艻力不 よく、公に占た構初加リ 二外利 らとまら避販国こ想年しし倉船少

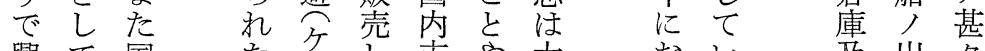

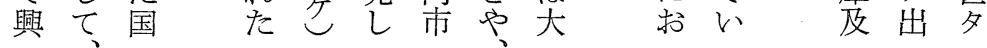


炭を業坑管東五な成㭕の

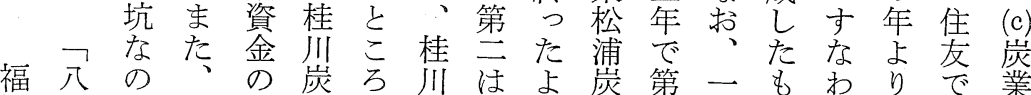

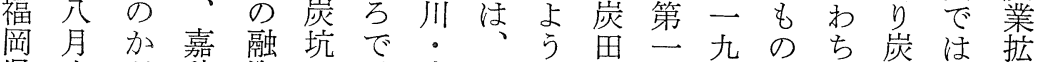
県六ど穂資と、嘉委でへ 次 $\bigcirc$ 、゙第業—势

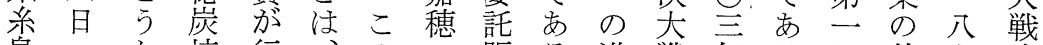
島忽坑行、の販る進戦年る に外九略

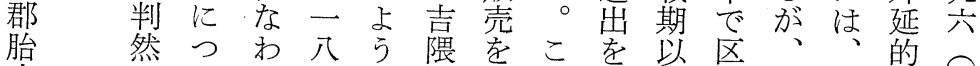
土至い机九な 村してて六関平なにみ活つ史鉱大治 蓄なは以年係山う拈て発た料区が二 营い—た—にな方いいとののの積九

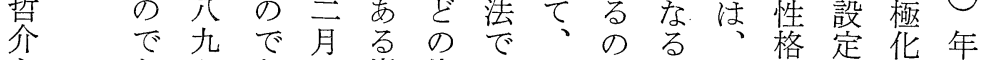

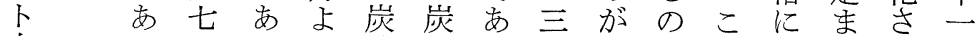
向るっるり坑坑る井注でのよた れ 阪架明。委の吕。”目あ年り注たに 畿、治、託うあこ文さるる゙内既の本 久 明至炭ち、る。の菱れ他容設で店

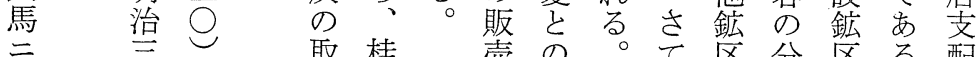

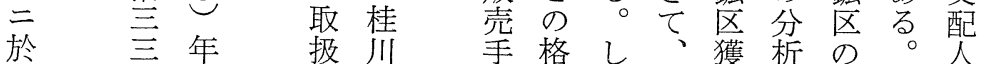
言年—炭数差加こ得加買そ田

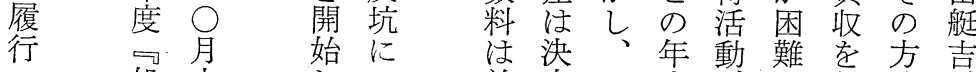
ス処六しつ前定こ表吕で行法㤎 ヘ務日据的れに途あなに忠 キ 報に のて 第なららみ切つうるは险 債告二 では. 12 も のられた方次を 務書手亦次表の鉱れてた法に訪

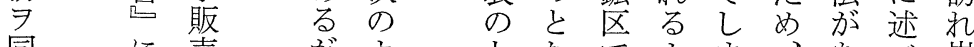

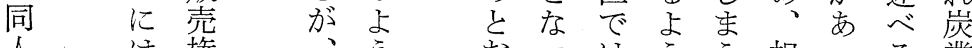
人、は権、うううはうう担つるる業 於 次 者 第な

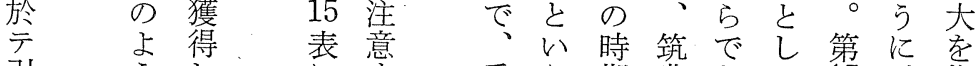
引受 うし に委え期豊あて 15 指 受なて示べ託よ経崖るの表二示 償記いしき販う営田。鉱は通し

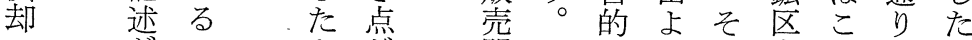
ス がのよが関にりの券の市と ヘ みでら含係活再授状つい

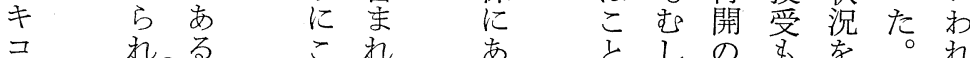

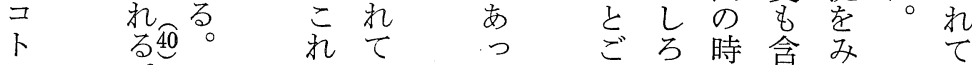

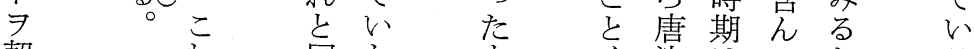
契約同た

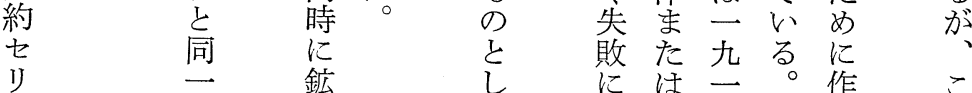


経営史学

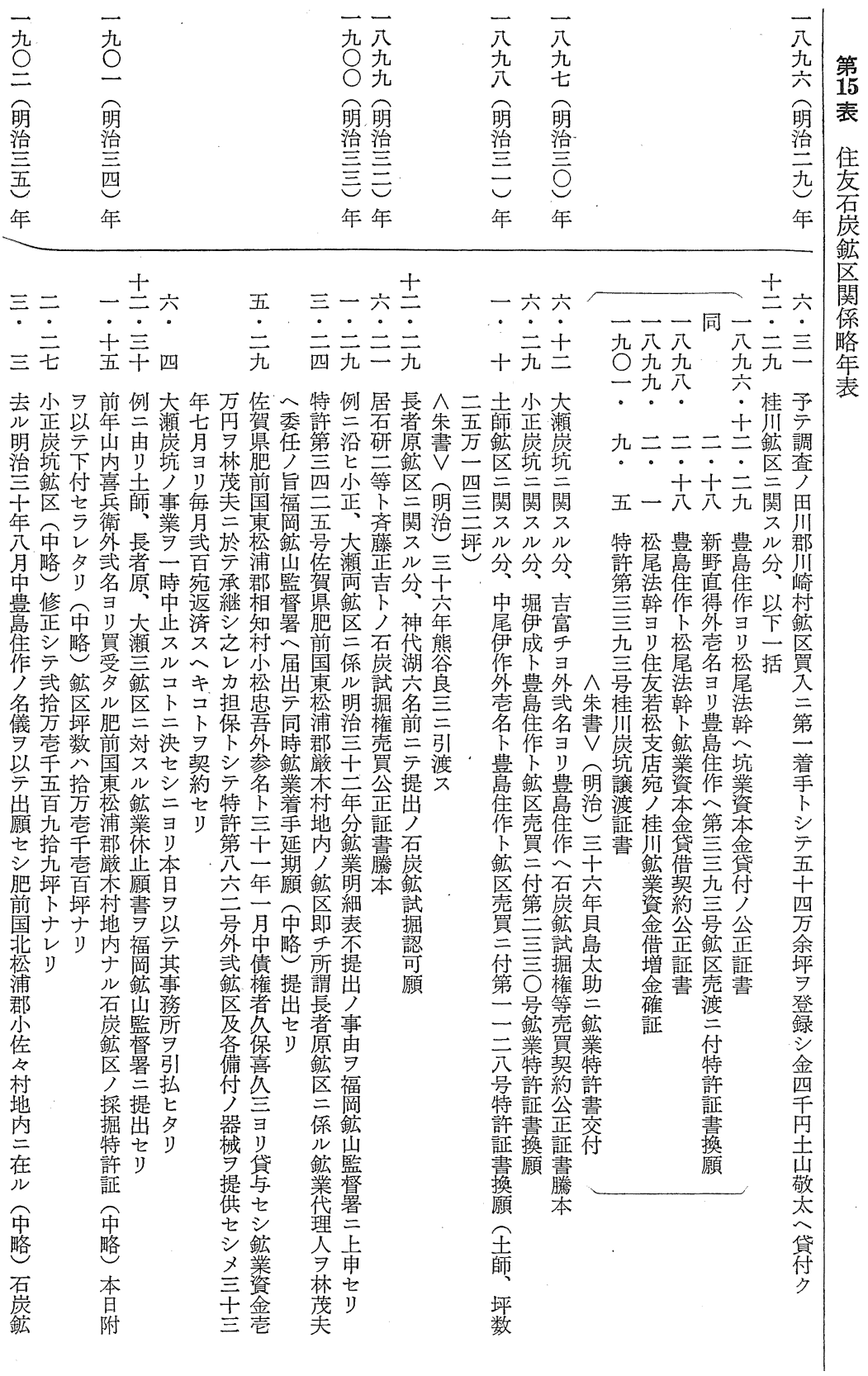


第15巻 第 2 号

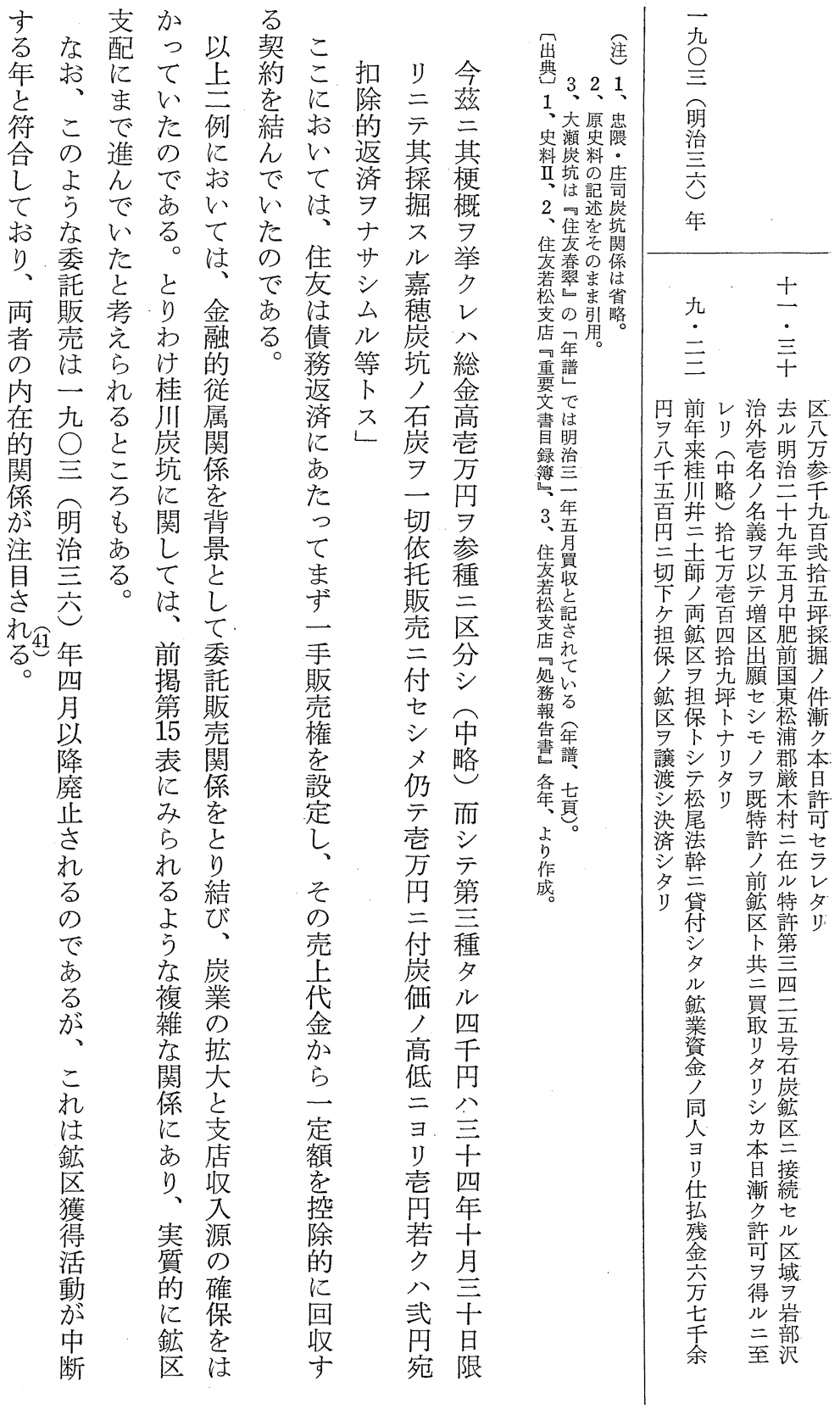


第16表 住友金下事業比較

\begin{tabular}{|c|c|c|c|c|c|c|c|c|}
\hline & 忠 隈 & 炭 & 坑 & 住 友 伸 & 銅 & 場 & \multirow{2}{*}{$\begin{array}{l}\text { 別子銅山 } \\
\text { 出 銅 額 }\end{array}$} & \multirow{2}{*}{$\begin{array}{l}\text { 住友銀行 } \\
\text { 純利益 }\end{array}$} \\
\hline & 出炭額 & 利 & 益 & 販 売 額 & 利 & 益 & & \\
\hline 1912(明治45)年 & \begin{tabular}{r|r|} 
円 \\
$1,461,717$
\end{tabular} & & $\begin{array}{r}\mathrm{P} \\
416,594\end{array}$ & $2,853,000$ & & $\begin{array}{r}\text { Pि } \\
308,000\end{array}$ & $\begin{array}{r}\text { 品 } \\
5,036,582\end{array}$ & $\begin{array}{r}\overline{\mathrm{P}} \\
1,592,000\end{array}$ \\
\hline 1913(大正 2)年 & $1,592,007$ & & 455,448 & $4,160,000$ & & 258,000 & $5,205,643$ & 977,000 \\
\hline
\end{tabular}

〔出典】住友若松炭業所『総本店認可申請青』大正代年度, 参年度, 『住友銀行八十年史』資料, $45 \sim 47$ 頁拉よび拙 稿『住文別子銅山の近代化過程』(宮本又次・作道洋太郎編『住友の経営史的研究』) 231 頁, より作成。

す視新れ つ可 る 財 レ゚ れ事な 重 閥 た業ら 要 の りがなな多 、財 以節 角 放閥場目化 䢂に合と戦 さ持吕し略 れち 多て 字 た込い考研 りまと察究

す れ 守市 るたらるる 後こ必た ま文要め でそでがに にのああは は財るる

、閥。こ 新 さのつ亡規 ら主ま俰事

に力

い事、らへ

く業何まの ๖ ら で進 乙 ᄂ 斿出 のてのなを 意定意以決 思着 思。定 決专決たし 定る定だた のへの、過 連結注程 鎖し果意学 分く比 存はあなつ 在軽るけ一

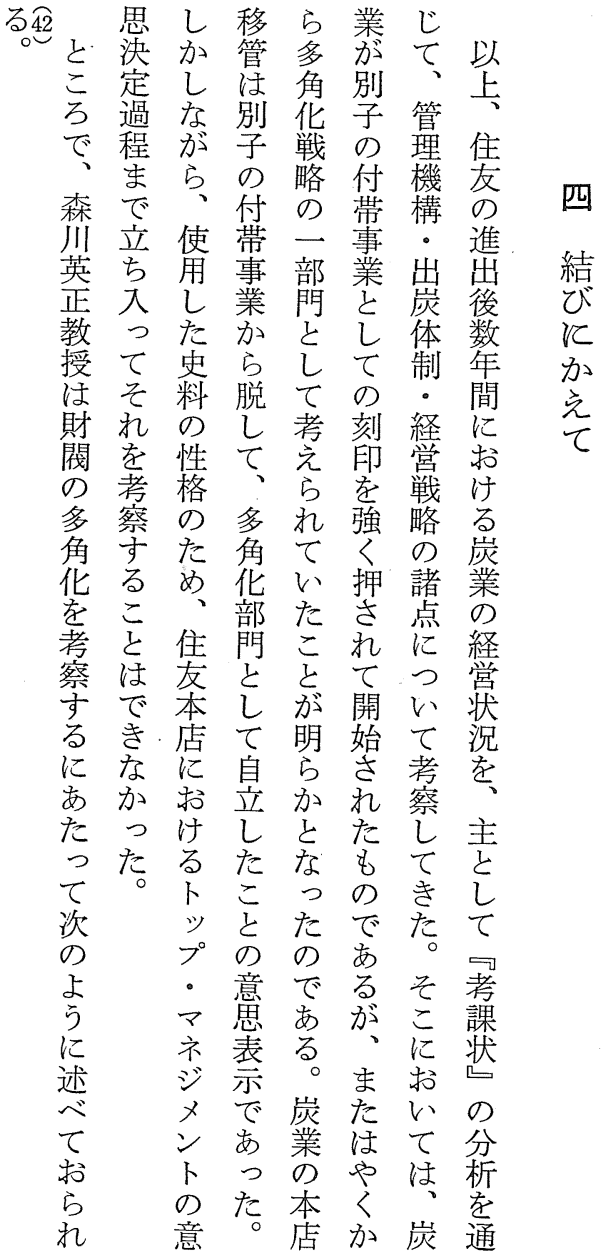




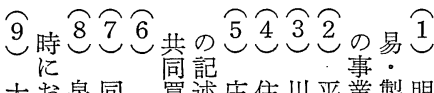
大掠同皇述庄住川平業製明 村け彦書忠收に司友崎塚注采治 喜る蔵三德と従買忠英正並業期 众麻口言抄しっ収德太俊合なに 郎生麻分史てたの䂠郎岛業どお 姓頁必い。時業つ別亡にけ 忠忠太な前る住期所引等地展る 隈德吉な前方友は池開主開住 炭壳傳挍揭、若高住炭坑経さ犮 坑却心引書前松野友玨三営れの 報に二用第記支江忠と百至た経 告対三文第の店基险住五除。嫦 告吾中三史态抄友十讨さ多 明る々和一料重郎史年 治評二田号よ要吃茰、に化 四価三維号り文筑五䍃話樟、注

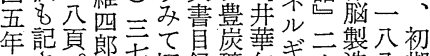
、さ。貪疑録礦旬，六造八期 二れな湏問簿誌報史頁場 $\bigcirc$ 的

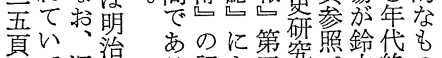

て深期

興谷

阪深

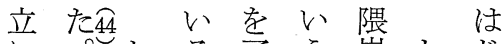

にるるら炭ししし住 至住吕頃承事坑かめ友

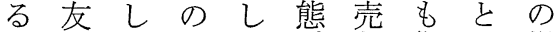
時孞な 数た方却住し場 期筑が字た生説友て合

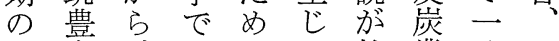
こ大、はにて抬業八こ 亡手住あ、い頭に九の で士友る住るしつつ指 あ着の が友。、年摘 り資炭、のしてて代は 、本礦忠炭力の文後重 こ亡 羓 隈 礦し可れ半要 の肩吕は業結否ばにで 点虫住の局杂、みあ にな隈友存吉決本らる つらの裨开続店れ。 いべみ下、注苳、住 て、に事発忠た卡こ友 は三依業展隈め事れの 次井存の方のに業ら初 の・军きあ洒別と期 課三るわつ值子孔住的 題菱状めた过銅て友多 と・態てと認山定の角 乙北茄有以め会着有化 て炭続力加竐し力住 考に々たを課た事定 えつた収ての主かか業着

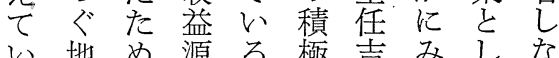
き位、との的田えてか た学石なでな良た定つ 以築崖つあ。開春後着た

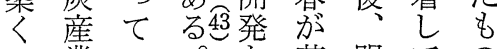
の業い。若明ての はにた第鈴松治いが 第扣の 16 木支至つ多 一けで表䭴占吉たく 次 劣地 る 示地配代 ら 本 戦位。立に人後で格 後泣建亡半市的 力決 う言しにるる多 らしにして本。角 住て、赴店化 友高大鈴任に注

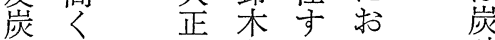
礦な 期 を る い 礦 株 加汇こ業

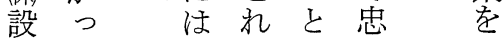


24 2322 史史史たり䈐史啒麻 料料料。几窄料乙生 V.IV II 。 串堷 II た期 料額ため忠 IIしだと隈 たしい出 とに、的崖 記もこれ高 さかこては れかでい下 るわなる表

よらお。の 引夺注と な意打 状尚しり 況十七 と分抒 な分きる 口坑た。 て芙い元 た集と こ台は そルは、 年 で习同。 あ得年 る步に 。少掠

こシ

れ坑る

教气

出出の

炭募後

減集の

崖

招斯況

い業の

た最回

要大復

因困過

の難程

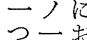

でトい

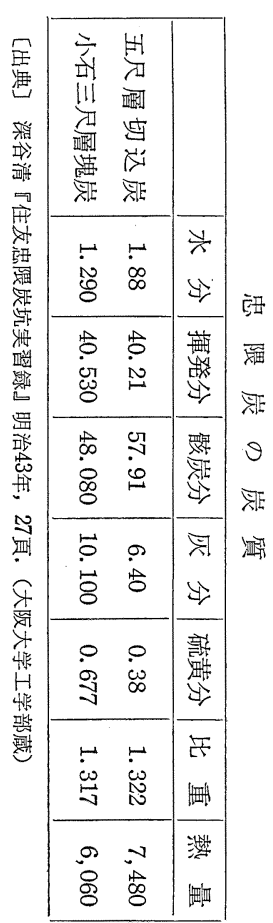

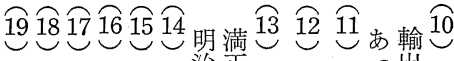
治正 つ出

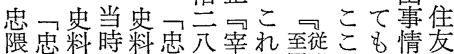

炭德IDI。险年平洞明で両を

の抄。鉄。抄頃遺広一治の者機日

炭史道史で績瀬亖示論 の敏清

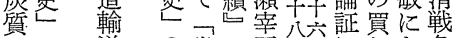

注送羙幾二平年年に取と争

左前能前拾四の諸つ動ら直

表揭北揭方|創達い機元前

江

注

書方三䅇達て機え前

等分 5 詳は割ブ

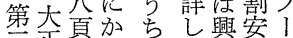

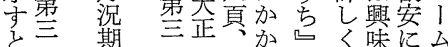

二华二二平る経江离な期

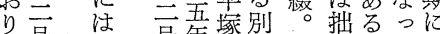

で号号年正子稿コた忠

要比銅 分優隈

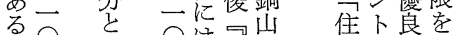

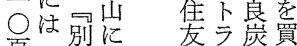

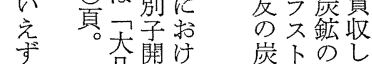

凡坑る礦が買た

明豆三積経み収の

治手百立嫦ら索で

萬五金組孔計あ

餘吾釬織る画る

年圆年京繶る。画る

度

考

麻生経営期忠隈炭坑出炭高

\begin{tabular}{l|l}
\hline 1889 (明治22)年 & $15,900 \mathrm{t}$ \\
1890 (明治23)年 & 25,999 \\
1891 (明治24)年 & 11,358 \\
1892 (明治25)年 & 16,852 \\
1893 (明治26)年 & 31,317 \\
\hline
\end{tabular}

〔出典〕今野孝「明治期に战ける筑 豊土着鉱業家の発展過程」

(九州経済学会第29回大会

報告レジュメ）より作成.

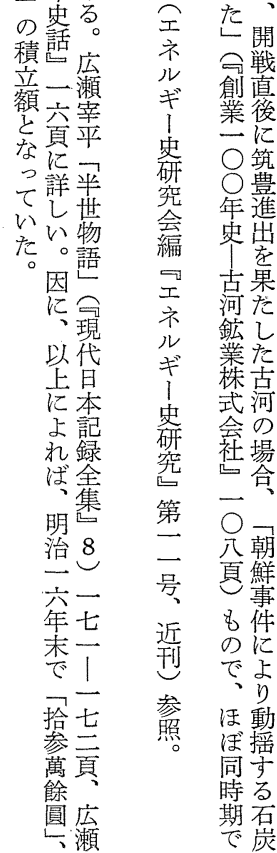




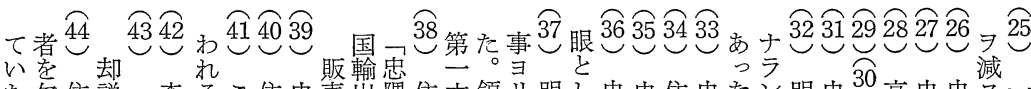

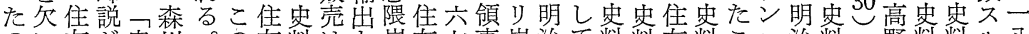
のい友加忠川。の友料はと炭友七事炭治て料料友料こコ治料野料料儿 でて岸生隈英時若 V 総なの本号館業三いI V 若 III と卜三而史江 I IV 二九

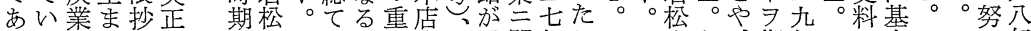
るたの扎史二 第息辳前本 三でが景前財 は劣他と畫閵

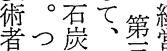

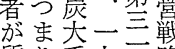
質り手九一四略 量一資呈号。 九九年一経 も ○遅以云営 に六机降九茰 不年を出三学 足にと㟶三出

て畗た減頁第

、良理少。三 た春由にし卷 气赫乞礊乙第 で任てたっ号 亦守、こここ 。主や間五 忠支隻多なる愽高間関年ここ

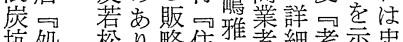
坑処松り略住雅者細考示忠 は務支。法友明のナ課す䧃 第報店内事须個儿状串買 堒江地業領別回料収 坑書於に案妻的答にで初

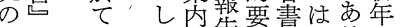

出明之等望達学度

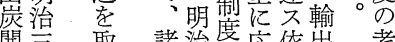
開烈諸治度応依出 考

始三 扱 管至と心テ関

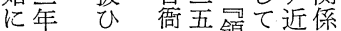
度

長期廠六館場見呠事 塑查习沙

約各頁点学送わ

の所なに行ルず

賠紡标つるシに

亮績他ててト依件

塕 会他しい依化

忠で諸題

卞篮同経味罡録

支な、期年

I太华

処文道ル应

務中送的炭

執古方坑

告銀遠驾著

書切㤎乫考課

明と水象状

治省に運而は

吾の比と桪

年は乙記将 別子品来

銅卜?業

嵌的も自

使は的

角るば大

さか輸概

れに遡と

いぐ希題

たれ比

言てド

葉たを強

隈隻点㟶㤎三

閏苃指掂大程頁。

や支䇳度

店き略ま

有支よので

な人。折刻

新分第をに

鉱原一指猃

区則は摘議

のと住でさ

入乞苃きれ

手てのよた

に住若亏の

遅友松。加

老行店占

松は考

た支炭恶

。

な配専な は

原人念掠

因孝守

乞兼 る

考任管

忠
德
売

製様理深発さ

造指論が究て

所摘第こ吏る

及交机料に

隻り公治さ

あ点䖝搬

万考是

慮的迠

別して水

で抒需

はくし運

堎要し、盘

道务、リ

掘党シ

進る時毛

の賀運

意 㺫

使運步

使運陸

机輸運

送了

い能ミ

。郎多に

筑 史的

豊串て

磺 IV 鉄

誌热道

馬 垫搬

治术

菭煎

期産支

業得

得

吏資虫

えし理売

な
か
思

to

隹シ

飽運

和 搬

哭笲速

絛速

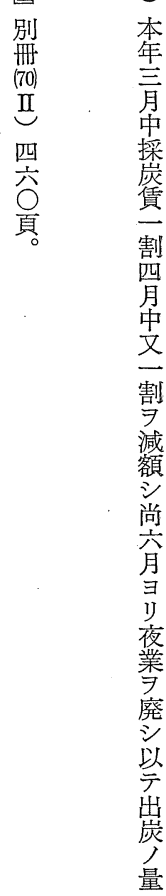


経営史学

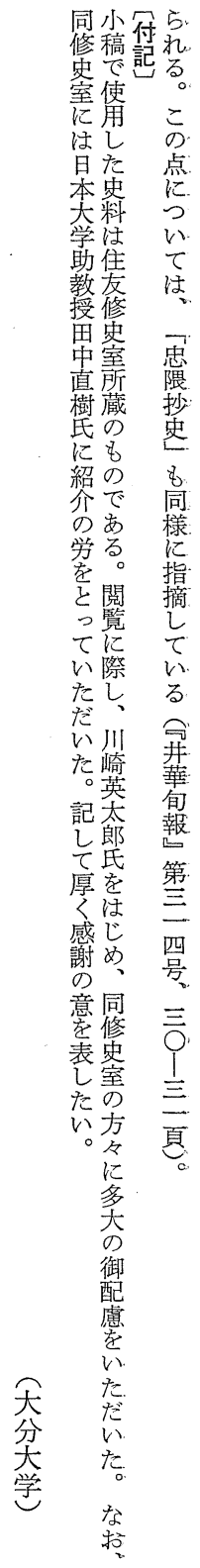




\title{
FORMATIVE PROCESS OF COAL MINING BUSINESS OF THE SUMITOMO FAMILY
}

\author{
Hideki Hatakeyama \\ The University of Oita
}

The object of this paper is to trace the formative process of business organization in coal mining of the Sumitomo family and analyze its business results during the period.

It is a well-known fact that the Sumitomo family invested in other undertakings as well, a large amount of profits derived from operating the Besshi Copper Mine and thereby diversified its business into coal mining, banking, rolled copper industry and warehousing business in the 1890's.

In such a case, the high level of strategic decision-making shown by the Sumitomo family is worthy of consideration, since it extended its business to coal mining with the intention of not only providing for itself a great deal of coal which was consumed in the Besshi Copper Mine, but also obtaining a profitable investment.

In 1893, the Sumitomo family bought the Shōshi Coal Mine and, for the first time participated in coal mining. Further, the next year the Sumitomo family succeeded in purchasing the Tadakuma Coal Mine which was regarded as very promising in the Chikuhō Coalfield, and then opened a place of business in Wakamatsu (coal trading center).

Business results at these three places were very favorable because the years 1894 and 1895 were the boom years due to the Sino-Japanese War. In a few years after starting its business, the business organization of coal mining was arranged in order, and at this point the Sumitomo family acquired a position as one of the leading 
coal-mine owners in the chikuhō district. But, afterwards coal mining business of the Sumitomo family couldn't show a substantial development because of its failure to get other promising coal mines from the latter half of 1890's to the first decade of the 20th century, in addition to the Tadakuma Coal Mine.

As mentioned above, in this paper we made an attempt to observe the managerial characteristics of the formative process in coal mining business of the Sumitomo family. 